\title{
Küresel Sistemde Devletlerarası Ekonomik Rekabetin Belirleyicileri: Körfez Ülkeleri İçin Bir İnceleme
}

\author{
Emre Saygin*-Tahsin Yamak ${ }^{* *}$
}

\section{$\ddot{O} z$}

Sanayi Devrimi sonrasında başlayıp çeşitli evreler geçiren küreselleşme olgusu, bilgi teknolojilerindeki gelişmeler ile birlikte özellikle 90'lı yıllarda hız kazanmıştır. $\mathrm{Bu}$ süreçte sosyo-külttürel, politik ve iktisadi ilişkiler üzerindeki zaman ve mekân sınırları kalkmış, işlem maliyetleri azalmak suretiyle iktisadi faaliyet daha rekabetçi bir alana kanalize olmuştur. Bu çalışmada, İkinci Dünya Savaşı ertesinde bağımsızlıklarını kazanmış otoriter-baskıcı monarşiler olarak bilinen Bahreyn, Birleşik Arap Emirlikleri, Katar, Kuveyt, Suudi Arabistan ve Umman'ın, ekonomik rekabet gücü performansı açısından küresel ekonomik sistem içerisinde nasıl bir konuma sahip oldukları analiz edilmiştir. Araştırma, Ortadoğu ülkelerinin temel sosyo-politik karakteristiğini açıklayan ve literatürde sıklıkla referans verilen "rantiyer devlet teorisi" etrafinda yürütülmüş, bu kapsamda uluslararası ekonomi politikte yaşanan paradigma değişimleri de dikkate alınmıştır. Körfez İş birliği Konseyi üyesi ülkelerin, "kaynakların laneti" olgusundan uzaklaşabilmek ve fakat aynı düzlemde rantiyer ilişki formlarını da muhafaza edebilmek maksadıyla modern altyapı sahibi mekânlar, bilgi toplumuna yönelen sektörler, dinamize edilmiş yerel üstünlükler ve artan faktör verimliliğine dayalı olarak ekonomik rekabet gücü performanslarını anlamlı ölçüde iyileştirdikleri anlaşılmıştır.

Anahtar Kelimeler: Ortadoğu, Körfez Arap Ülkeleri, Rantiyer Devlet, Rekabet Gücü, Verimlilik.

JEL Sınıflandırması: N15, P48, F63.

\footnotetext{
Dr. Emre Saygin, sayginemre@gmail.com

** Dr. Tahsin Yamak, tahsinyamak@gmail.com
} 


\title{
Determinants of Inter-state Economic Competition in Global System: Analysis for the Gulf Countries
}

\author{
Emre Saygın*-Tahsin Yamak*
}

\begin{abstract}
The phenomenon of globalization, which began after the Industrial Revolution and underwent several phases, has gained momentum in the 1990s, especially with advances in information technology. In this process, the boundaries of time and space on socio-cultural, political and economic relations have been gone and economic activity has been channeled into a more competitive field by reducing transaction costs. In this study, it will be analyzed how Bahrain, United Arab Emirates, Qatar, Kuwait, Saudi Arabia and Oman, known as authoritarian-oppressive monarchies that gained their independence in the Second World War, have a place in the global economic system in terms of economic competitiveness performance. The research has been conducted around the "rentier state theory," which explains the basic socio-political character of the Middle Eastern countries and is frequently referred to in the literature, and paradigm shifts in international political economy will be considered in this context. It has been understood that GCC member countries significantly improve their economic competitiveness performance based on modern infrastructure, sectors oriented to the information society, dynamical local supremacy and increased factor productivity in order to be able to move away from the "curse of resources" and retain the ranting relationship forms on the same plane.
\end{abstract}

Keywords: The Middle East, GulfArab Countries, Rentier State, Competitiveness, Productivity.

JEL Codes: N15, P48, F63.

* Dr. Emre Saygın, sayginemre@gmail.com

** Dr. Tahsin Yamak, tahsinyamak@gmail.com 


\section{Giriş}

\section{Küreselleşmenin Rekabetçilik Vizyonu ve Ortadoğu}

Küreselleşme politik, ekonomik, sosyal, kültürel ve sair her boyutuyla gerek makro düzeyde devlet-toplum-piyasa arasındaki etkileşimin gerekse mikro düzeyde insanlar arası ilişkilerin formunu belirleyen etkili ve baskın bir fenomendir. Öyle ki en kapalı/korumalı ekonomiler, katılımc1lıktan uzak siyasal yapılar ve/veya kadim/yerleşik kültürel formlar dahi bu süreçten ari kalamamakta, iradi veya gayri-iradi bir surette evrensel değerler olarak tanımlanan söz konusu sürecin bir parçası oluvermektedirler.

İyi-kötü, kapsayıcı-dışlayıcı gibi birçok farklı şekilde tanımlanan kurallar, organizasyonlar ve kurumlardan müteşekkil olan devlet-toplum-piyasa ilişkileri açısından değiştirici ya da dönüş̧ürücü birtakım etkilere sahip olan küreselleşme olgusu, bahsi geçen etkilerin iç ya da dış kaynaklı olmas1, geçici veya kalıcı etkiler ortaya çıkarması, olumlu ya da olumsuz olarak nitelenmesi gibi tartışmalar bir tarafa bırakılacak olursa, kaçınılmaz bir gerçekliği ifade etmektedir.

$\mathrm{Bu}$ gerçeklik, iktisadi veçhesi itibarıyla ekonomik aktiviteye ilişkin ulus devletlerin korumacı politikalarını yumuşattığı yani sınırların gevşediği, ekonomik ve finansal ilişkilerin hızlandığı ve yoğunlaştığı, hatta konjonktürel daralmalar dışında giderek daha da genişlediği bir sistematiği ifade etmektedir. Küresel ekonomik ilişkiler bütününün en temel/önemli aktörlerinden olan devletler açısından ise bu durumun en somut çıktısı artan rekabet ortamı olmakta; genel olarak verimlilik düzeyini yükselterek rekabetçi özellik kazanabilen devletler vatandaşlarının genel yaşam kalitesini de yükseltmeyi başarabilmektedirler.

Kuşkusuz bu her devletin ulaşmayı amaçladığı bir hedef olmakla birlikte, biraz evvel de belirtildiği üzere, geçmişten süregelen formel ve enformel kurumsal yapılarını değiştirerek/dönüştürerek politik, ekonomik ve sosyal ilişkilerde gri/muğlak alanların en aza indirildiği ve böylece etkinliğin arttırılması suretiyle rekabetçi özelliğin geliştirildiği sürdürülebilir bir ivme yakalamak kolay olmayabilmektedir. Mevcut düzenin temellerini atan Batı medeniyetinin gelişmiş ülkeleri günümüzde sistemin taşıyıcıllğını sürdürmekte ve fakat farklı kurallar ve ilişki formları üzerine kurulan Ortadoğu ülkeleri, bahsi geçen değişim/dönüşüm hamlelerini gerçekleştirmekte mahir bir görünüm arz etmemektedirler. 
Jeostratejik özellikleri itibarıla nadide bir konuma sahip olan Ortadoğu ülkeleri, söz konusu özelliklerinin avantajlarından çok dezavantajları ile yüzleşmek durumunda kalmaktadırlar. Kadim siyaset geleneği, zengin doğal kaynakları ve çoklu kültürel yapılarını kurumsal bir devlet yapılanmas1, güçlü bir ekonomi ve müreffeh bir toplumsal hayata tahvil edemeyen Ortadoğu ülkeleri otoriter-baskıcı yönetimler, oldukça adaletsiz bir gelir dağılımı ve yüksek işsizlik ile etnik ve dini temelli mikro-kültürel çatışmalar içinde adeta istikrarsızlığın tarihini yazmaktadırlar. Ancak, bu durum karşısında dahi Ortadoğu devletlerinin, politik ve kültürel alanlarda olmasa da ekonomik anlamda mevcut yapılarını, temellerini muhafaza etmek ve fakat bazı rekabetçi unsurlar katıştırmak suretiyle revize ederek kendilerine özel bir rekabet gücü kazanma hamlesine giriştikleri de bilinmektedir.

İşte bu çalışmanın hedefi, sahip oldukları doğal kaynak rezervlerinin yüksekliği nedeniyle enerji merkezli bir ekonomik yapıya mahkûm olduğu bilinen ve devlet-toplum-piyasa ilişkileri genellikle rantiyer devlet teorisi etrafında açıklanabilen Körfez Arap Ülkeleri İşbirliği Konseyi (Cooperation Council for the Arab States of the Gulf-GCC) üyesi Bahreyn, Birleşik Arap Emirlikleri, Katar, Kuveyt, Suudi Arabistan ve Umman'da politik katılımc1lık, ifade ve örgütlenme hürriyeti ile diğer temel hak ve özgürlükler, hukukun üstünlüğü ve etkin yarg1 sistemi, patrimonyal ilişkiler ve yolsuzluğun kontrolü gibi siyasal ve sosyal kurumlarda belirgin (hatta neredeyse hiç) bir iyileşme görülmemesine rağmen, küreselleşme sürecindeki gelişmelerin de itici etkisi ile iş ve yatırım piyasasına yönelik kapsayıcı düzenlemeler yaparak ve özellikle belirli hizmet sektörlerinde hızlı ve düşük işlem maliyetli işleyen yapı inşa ederek ekonomik kurumlar bağlamında nasıl bir değişim/dönüşüm gerçekleştiğinin, ekonomik rekabet gücü unsurları özelinde analiz edilmesidir.

$\mathrm{Bu}$ doğrultuda, zaman zaman literatürde yer alan temel çalışmalara referans verilecek, bazen ise erişilebilen nicel verilerden oluşturulan şekil ve tablolar etrafında açıklamalar sunulacaktır. Araştırmanın temelini oluşturan kurumlar ve rekabet gücü performansına ilişkin göstergeler içinse, ileriki bölümlerde tercih nedenleri sunulmak kaydıyla, Dünya Ekonomik Forumu tarafindan yayımlanan Küresel Rekabet Gücü Endeksi'nin ana ve alt bileşenleri esas alınacaktır. Öte yandan kısmen Dünya Bankası tarafından hazırlanan Dünya Yönetişim Göstergeleri ile çeşitli uluslararası kuruluşlar ya da düşünce kuruluşlarınca ortaya konulan muhtelif kapsamdaki endekslere de başvurulacaktır. 


\section{Ekonomik Rekabet Gücünün Tetikleyici Unsuru: Verimlilik}

Sürekli bir gelişim seyri içerisinde bulunan iktisat bilimi içerisinde istikrarl1 ekonomik büyümenin sağlanması, sürdürülebilir kalkınma hamlelerinin gerçekleştirilmesi ve refah düzeyinin arttırılmasına yönelik politika ve uygulamaların tespit edilmesi esaslı ve merkezi bir yer tutmakta; açıklama ve izahat bekleyen pek çok sorunsalı uhdesinde barındıran bu karmaşık alan, bu cihetiyle iktisatçıları inter-disipliner çalışmalara teşvik eden bir nitelik arz etmektedir. Zira ülkelerarası ekonomik büyüme oranı ile kalkınma ve refah düzeyi farkl111klarının sebeplerine dair teorik düzlemde muhtelif kuramsal açıklamalar geliştirilmekteyse de anaakım iktisadi doktrin, özellikle benzer sosyolojik, demografik, coğrafi ve kültürel değişkenlere sahip ülkelerin rekabet güçleri arasındaki ciddi farklılıkların nedenlerinin açılanması ve bu nedenlerin belirleyici unsurlarının tespiti hususunda yetersiz kalmaktadır. Bu noktada rekabet gücü̈ kavramının neyi ifade ettiğinin açıklanması önem taşımaktadır.

Birçok farklı tanımı yapılagelen rekabet gücü hakkında Dünya Ekonomik Forumu (World Economic Forum-WEF), Ekonomik İşbirliği ve Kalkınma Örgütü (Organisation for Economic Co-operation and DevelopmentOECD), Uluslararası Kalkınma Yönetimi Enstitüsü (International Institute for Management Development-IMD), birbirlerine benzer tanımları esas almakta ve rekabet gücü kavramını, refah artışına dönüşen piyasa başarısı olarak ifade etmekte; ${ }^{2}$ Michael Porter ise refah seviyesinin temel belirleyicisinin verimlilik olduğunu öne sürerek rekabet gücü ile verimliliği adeta birbirine denk tutmaktadır. ${ }^{3}$

Esasen statik bir kavram olan ve en basit anlamda katma değer üretme becerisi olarak tanımlanan ya da çıktı/girdi oranı olarak ifade edilen ve

1 Esasen "rekabet” ve "rekabet gücü” kavramlarını hakkında üzerinde uzlaşma sağlanmış bir tanımın ve yeknesak özellik taşıyan bir kapsamın bulunduğunu söylemek zordur. Bu nedenle, çalışmanın sınırları da dikkate alınarak, anılan kavramlara ilişkin tartışmalara girilmeyecek; analize konu Küresel Rekabet Gücü Endeksi'nin ana ve alt bileşenleri ekonomik rekabet gücünün belirleyicileri olarak ele alınacaktır. Konuya ilişkin detaylı bir literatür araştırması için bkz. Emin Çivi, "Rekabet Gücü: Literatür Araştırması," Yönetim ve Ekonomi 8, no. 2 (2001): 22-38.

2 Tai-Yue Wang ve Diğerleri, “A Research Framework for Evaluating the Competitiveness of Developing Countries: An Example of the Philippines," Asia Pacific Management Review 9 no. 2, (2004): 301-21.

3 S.M. Gökmenoğlu ve Diğerleri, "Ulusal Rekabet Gücünü Belirleyen Faktörler Üzerine Değerlendirmeler," Rekabet Dergisi 13 no. 4, (2012): 5. 
rekabet gücünün açıklanmasında da kilit rolü bulunduğu görülen verimlilik kavramı, işletme, endüstri ya da ülke düzeyinde ölçülebilmektedir. Bu bağlamda eğitim, kapasite kullanım oranlarının arttırılması, çalışma ortamının iyileştirilmesi ve benzeri sebeplerle, mevcut teknolojik imkânlar dâhilinde gerçekleştirilen verimlilik artışlarına mikro verimlilik, teknolojik yeniliklere dayalı olarak yeni ürünler ya da üretim yöntemlerine başvurmak suretiyle elde edilen verimlilik artışlarına ise makro verimlilik adı verilmektedir. ${ }^{4}$

Her iki tür verimliliğin ölçülmesine yönelik olarak yürütülen araştırmalar da teknolojik gelişim, eğitimin kalitesi, hükümet politikaları, çalışma koşulları ve sair çeşitli faktörlerin verimlilik üzerinde önemli ve anlamlı etkilerinin bulunduğunu ortaya koymakta, böylece verimlilikte meydana gelen artışların ekonomik rekabet gücünün geliştirilmesi dolayısıyla ekonomik performansın yükseltilmesi noktasında önemli bir açıklayıcı değişken olduğu görülmektedir. ${ }^{5}$

Buna göre, küreselleşmenin ortaya koyduğu yoğun ve rekabetçi piyasaların dalgalı konjonktürel seyri içerisinde devletlerin, kaynak dağılımında etkinliği sağlayacak, piyasa aksaklıklarını giderecek, pozitif dışsallıklar oluşturabilecek ve belirsizlikleri gidererek işlem maliyetlerini azaltabilecek kapsayıcı kurumsal yapıları oluşturmaları beklenmektedir. Esasen devletlere yüklenen bu sorumluluklar, küreselleşme olgusu ile birlikte devlete biçilen yeni role de yakınlık göstermektedir. Şöyle ki sürdürülebilir kalkınma hamlesinin gerçekleşmesinde yönetimin ortak, hızlandırıcı ve kolaylaştırıcı bir rolünün bulunduğu gerçeğinden hareketle, ekonomik hayatın canlanması için çeşitli kurallar ve kurumların oluşmasına imkân sağlayarak rekabetçilik özelliğini destekleyen etkin devlet modelinin ön plana çıkmakta olduğu söylenebilmektedir. ${ }^{6}$

4 Hasan Gürak, Ekonomik Büyüme ve Küresel Ekonomi (Bursa: Ekin Kitabevi, 2006), 45-67.

5 Xavier Sala-i-Martin ve Diğerleri, "Reaching Beyond the New Normal: Findings from the Global Competitiveness Index 2015-2016," The Global Competitiveness Report 2015-2016, ed. Klaus Schwab, (2015): 43.

6 Anaakım iktisadi doktrinin güncel ekonomik problemler karşısındaki geleneksel ve soyut tutumunu sorgulayan ve çözüm önerilerini "kurum" kavramı ekseninde oluşturan Kurumsal İktisat Okulu'nun detayları için bkz. Douglass C. North, Kurumlar, Kurumsal Değişim ve Ekonomik Performans, çev. Gül Çağalı Güven (İstanbul: Sabanc1 Üniversitesi Yayınlan, 2002); Öte yandan ülkeler arasındaki gelişmişlik farklılıklarının açıklanmasında kurumsal kalitenin önemine vurgu yapan bir çalışma için bkz. Daron Acemoğlu ve James A. Robinson, Ulusların Düşüşü - Güç, Zenginlik ve Yoksulluğun Kökenleri, çev. Faruk Rasim Velioğlu (İstanbul: Doğan Kitap, 2013). 
Etkin devlet, vatandaşlarının daha müreffeh bir yaşam sürmelerine imkân sunan düzenlemelerde bulunan ve bunu yaparken de temel hak ve özgürlüklerin korunması ile politik katılımcılığın sağlanmasına özen gösteren yönetim biçimini işaret etmektedir. Başta kamu kesimi olmak üzere, özel sektör ve sivil toplum kuruluşlarını da içeren ve bu organizasyonlar arasındaki yatay ve dikey etkileşimlerin ideal düzeyde bulunması halini ifade eden yönetişsim kavramı etrafinda şekillenen söz konusu tartışmalarda, ekonomik faktör verimliliği ve kaynakların şeffaf ve hesap verilebilir şekilde yönetilmesi ekseninde devletin sınırları adeta yeniden çizilmektedir. ${ }^{7}$

Bu bağlamda etkin devletler, değişen şartları da göz önünde bulundurarak küresel rekabet güçlerini arttırmak maksadıyla, beşeri sermayelerini güçlendirmek, mal ve faktör piyasalarının etkinliğini arttırmak, finansal piyasalarını derinleştirmek, teknolojik kapasitelerini arttırmak ve çeşitli inovatif yeniliklerde bulunmak için birçok farklı düzenlemeyi hayata geçirmektedirler. Böylece devletlerin rekabet güçleri yükselmekte, bu durum faktörlerin verimlilik düzeylerini önemli ölçüde arttırmakta, artan faktör verimliliği ile birlikte ekonomik büyümenin arttırılması ve bu yolla kalkınma ve refah hamlelerinin yapılması sağlanmaktadır. Adeta bir mekanizmanın dişlilerinin dönmesi şeklinde düşünebileceğimiz bu devinim, çift yönlü etkiler ortaya çıkarmaktadır. Rekabet gücünün arttırılması, verimlilik artışına sebebiyet verirken, artan refah ve kalkınma hamlelerinin de verimlilik artışı ile birlikte küresel rekabet gücünün yükseltilmesine katkısı bulunmaktadır. Kısacası bu etkileşim süreci, birbirini destekleyerek çift yönlü etki doğuracak şekilde çalışmaktadır.

\section{Rekabet Gücü Performansının Nicel Olarak Ölçülmesi}

Kuşkusuz bir ülkenin rekabet gücü sosyal, ekonomik, politik ve sair fark11 disiplinlere ait nitel ve nicel birçok parametreyi içerebilir. Bir taraftan bütün bu parametrelerin sayısal verilere dönüştürülmesi, diğer taraftan ise belirli bir sistematik dâhilinde derlenmesi oldukça zor bir süreci ifade etmektedir. Bu bağlamda akademik kurumlar, uluslararası kuruluşlar, sivil toplum ve/veya düşünce örgütleri tarafından, başta anket olmak üzere

7 Ahmet Faruk Aysan, "Yönetișim ve Kurumlar Kavramlarının İktisat Literatüründeki Yükselişi Üzerine Bir Değerlendirme,” Uluslararası Ekonomi ve Dış Ticaret Politikaları Dergisi 1 no. 2 (2007): 30-1. 
farklı birtakım metotlar kullanılarak oluşturulmuş, sadece kapsamlı ya da münferit unsurları barındıran kısıtlı muhtelif veri setleri mevcuttur. ${ }^{8}$

Bir sonraki paragrafta kısaca bahsedilecek olan söz konusu endekslerin en önemli özelliği araştırmacılara belirli bir dönem için, düzenli nicel veriler etrafinda analiz yapma imkânı sunmalarıdır. Ancak bahsi geçen veri setlerinin, dönemsel etkilerin arındırılmaması sonucu ortaya çıkan öznellik, aktörler-arası farkl111kları ihtiva etmemesi nedeniyle oluşabilecek içsellik ve işbu endeksleri veri olarak kabul edecek kişilerin yönlendirici hamlelerinden kaynaklanan yanlılık gibi sorunları bulunmaktaysa da söz konusu olumsuz etkilerin bir takım ekonometrik ve istatistikî modellemeler yoluyla ortadan kaldırılabileceği bilinmekte, böylece endekslerin güvenilirlik düzeyinde herhangi bir negatif yön bulunmamaktadır.9

Ülkelerin küresel rekabet gücüne dair göstergeler barındıran endeksler, mahiyetleri itibarıyla kapsamlı ve kısıtlı olmak üzere iki şekilde sınıflandırılmaktadırlar. Genel olarak tanımlayacak olursak, kapsamlı endeksler farklı birçok disipline ait göstergelerin bir arada değerlendirildiği çok yönlü veri setini işaret etmekte iken, kısıtlı endeksler ise spesifik bir alana odaklanmak suretiyle tek bir kuruma ve/veya ilgili kurumun alt başl1klarına odaklanan veri setini ifade etmektedir. Literatürde sıklıkla referans verilen endekslerden bazıları; Dünya Bankası'nın hazırladığı Dünya Yönetişim Göstergeleri, ${ }^{10}$ Dünya Ekonomik Forumu'nca yayımlanan Küresel Rekabet Gücü Endeksi, ${ }^{11}$ Fraser Enstitüsü'nün hazırladı̆̆ 1 Dünya Ekonomik Özgürlük Endeksi, ${ }^{12}$ Freedom House tarafindan yayımlanan Dünya'da Özgürlükler Endeksi, ${ }^{13}$ Heritage Vakfi ve Wall Street Journal

$8 \mathrm{Bu}$ veri setleri arasındaki uyum ve çelişkilerin detaylı olarak incelendiği çalışma için bkz. Steve H. Hanke ve Stephen J. K. Walters, "Economic Freedom, Prosperity and Equality: A Survey," Cato Journal 17 no. 2 (1997): 121.

9 Mehmet Uğur, "Kurumsal Kalite ve Ekonomik Performans-İktisadın (Yeniden) Siyasallaşması mı?," İktisat ve Toplum no. 9 (2011): 39-40.

10 Metodolojisine ilişkin detaylı bilgi için bkz. Daniel Kaufmann, Aart Kraay ve Massimo Mastruzzi, "The Worldwide Governance Indicators - Methodology and Analytical Issues," The World Bank Policy Research Working Paper no. 5430 (2010): 2.

11 Bir sonraki bölümde detaylı olarak açıklanacaktır.

12 Metodolojisine ilişkin detaylı bilgi için bkz. James D. Gwartney ve Diğerleri, "Economic Freedom of the World: 2010 Annual Report," Fraser Institute Report (2010): 1-3.

13 Metodolojisine ilişkin detaylı bilgi için bkz. Freedom House, Freedom in the World 2013-Methodology, 21.10.2013, http://www.freedomhouse.org/report/freedomworld2013/ methodology. 
tarafından müştereken hazırlanan Ekonomik Özgürlükler Endeksi, ${ }^{14}$ Politik Risk Hizmetleri Grubu'nca yayımlanan Uluslararası Ülke Risk Rehberi, ${ }^{15}$ Dünya Bankası ile Uluslararası Finans Kurumu'nca hazırlanan İs Yapma Endeksi, ${ }^{16}$ Ekonomist Dergisi'nce yayımlanan Demokrasi Endeksi, ${ }^{17}$ Uluslararası Şeffaflık Örgütü'nce hazırlanan Yolsuzluk Algllama Endeksi ${ }^{18}$ ve Mülkiyet Hakları Birliği'nce yayımlanan Uluslararası Mülkiyet Hakları Endeksi ${ }^{19}$ gibi veri setleridir.

Çalışmanın ilerleyen bölümlerinde zikredilen endekslerin birçoğuna atıf yapılacak ise de, araştırmanın özü itibarıyla Dünya Ekonomik Forumu tarafindan üretilen Küresel Rekabet Gücü Endeksi ayrıca önem ve farklılık arz etmektedir. Şöyle ki veri setinin kapsamı ve analitik yapısı yanında ihtiva ettiği risk ve verimlilik göstergeleri, ülkelerin rekabet gücü performansını anlamlandırmak ve yorumlamak için ideal bir altyapı sunmaktadır. $\mathrm{Bu}$ nedenlerden dolayı, adı geçen endeksin teorik altyapısının ve metodolojisinin gözden geçirilmesinde fayda mülahaza edilmektedir.

14 Metodolojisine ilişkin detaylı bilgi için bkz. Terry Miller ve Anthony B. Kim, "Defining Economic Freedom,” Index of Economic Freedom 2014, ed. Terry Miller ve Diğerleri (The Heritage Foundation and The Wall Street Journal Report, 2014): 79-86.

15 Metodolojisine ilişkin detaylı bilgi için bkz. The Political Risk Services (PRS) Group, International Country Risk Guide Methodology, 16.06.2014 http://www.prsgroup. com/wp-content/uploads/2012/11/icrgmet hodology.pdf, 1 .

16 Metodolojisine ilişkin detaylı bilgi için bkz. World Bank, Doing Business 2014 (2013): $1-2$.

17 Metodolojisine ilişkin detaylı bilgi için bkz. Economist Intelligence Unit, Democracy Index 2014- Democracy and Its Discontents (2015): 1.

18 Metodolojisine ilişkin detaylı bilgi için bkz. Transparency International, Corruption Perceptions Index 2013-Brochure (2013).

19 Metodolojisine ilişkin detaylı bilgi için bkz. Property Rights Alliance, International Property Rights Index 2013 (2013): 8. 


\section{Şekil 1: Küresel Rekabet Gücü Performansının Bileşenleri}

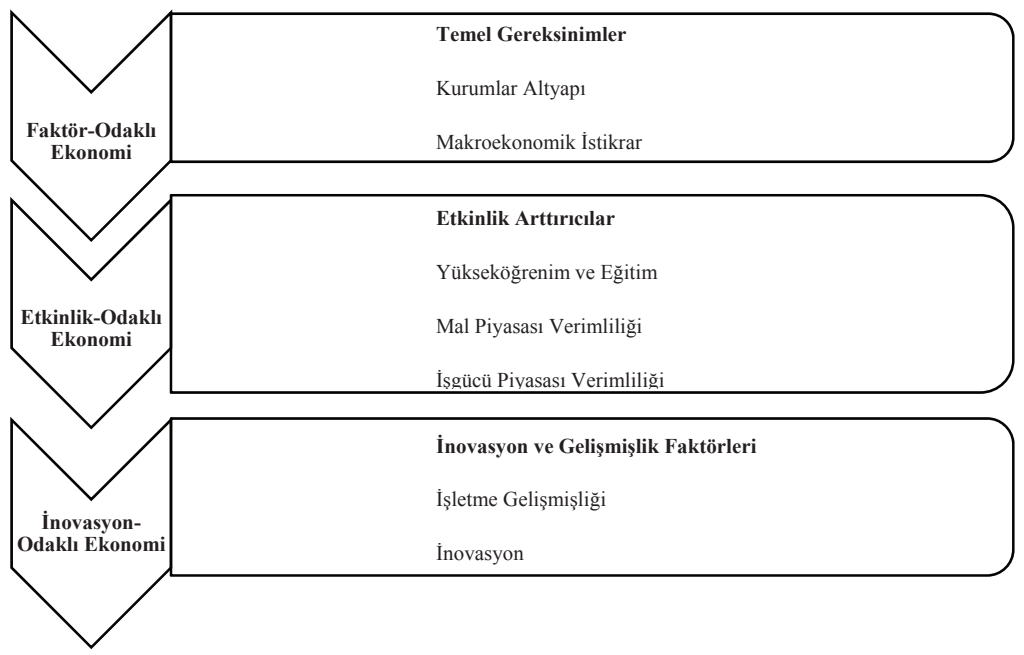

Kaynak: World Economic Forum, The Global Competitiveness Report 2016-2017, ed. K. Schwab (2016): 5.

Dünya Ekonomik Forumu tarafindan 1979 yılından bu yana yüze yakın mikro ve makro göstergeyi esas almak kaydiyla üretilip Küresel Rekabet Gücü Raporu başlığıyla yayımlanan Küresel Rekabet Gücü Endeksi, Şekil 1 'de de görülebileceği üzere temel alarak; kurumlar, altyap1, makroekonomik istikrar, sağl1k ve ilköğrenim gibi temel gereksinimler; yükseköğrenim ve eğitim, mal piyasası verimliliği, işgücü piyasası verimliliği, finansal piyasaların gelişmesi, teknolojik hazırlık, piyasa büyüklüğü gibi etkinlik arttırıcılar; işletme gelişmişliği, inovasyon gibi inovasyon ve gelişmişlik faktörleri olmak üzere üç ana alan etrafında son derece detaylı nicel veriler sunulmaktadir. ${ }^{20}$

Anılan üç ana alanda yer alan on iki bileşenin genel olarak hangi hususları kapsadığına Tablo 1'de kısaca değinilmiştir.

20 Dünya Ekonomik Forumu tarafindan yayımlanan Küresel Rekabet Gücü Raporundaki kavramların Türkçe karşılıkları belirlenirken, Ali Cevat Taşıran ve Burçak Özoğlu tarafindan hazırlanan, Kuzey Kıbrıs 2016- 2017 Rekabet Edebilirlik Raporu (Kıbris Türk Ticaret Odası, 2017) içerisindeki kullanımlar esas alınmıştır. 
Tablo 1: Küresel Rekabet Gücü Bileşenlerinin Kapsamı

\begin{tabular}{|c|c|c|}
\hline $\begin{array}{l}\text { Ana } \\
\text { Alan }\end{array}$ & Alt Faktör & Açıklama \\
\hline \multirow{4}{*}{ 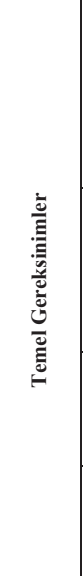 } & Kurumlar & $\begin{array}{l}\text { Bu bileşen, kişilerin, firmaların ve devletin refah artışı sağlamak üzere } \\
\text { etkileşim içerisinde bulunduğu formel/hukuki ve idari çerçeveyi ifade } \\
\text { etmektedir. Yolsuzluğun önlenmesi, ifade özgürlüğ̈ ve hesap } \\
\text { verilebilirlik, yönetimin etkinliği ve bürokrasinin basitleştirilmesi gibi } \\
\text { unsurlardan oluşan kurumsal kalite doğrudan yabanc1 sermaye yatırımları } \\
\text { ve endüstriyel planlamalara doğrudan etki ettiğinden dolayı küresel rekabet } \\
\text { gücü üzerinde etkili olmaktadır. }\end{array}$ \\
\hline & Altyapı & $\begin{array}{l}\text { Bu bileşen, yaygın ve kaliteli bir fiziki altyapının, piyasaların birbirine } \\
\text { yakınlaşmasını ve böylece ticari faaliyetin hız kazanmasını temin ederek } \\
\text { verimlilik ve dolayısıyla rekabetçiliği arttırmasını ifade etmektedir. } \\
\text { Ayrıca, bilgi iletişim altyapısındaki gelişmeler sayesinde hızlı ve düşuk } \\
\text { maliyetli bilgi akışını sağlanması suretiyle elde edilecek rekabet avantajı } \\
\text { da bu bileşen kapsamında değerlendirilmektedir. }\end{array}$ \\
\hline & Makroekonomik İstikrar & $\begin{array}{l}\text { Bu bileşen, fiyat istikrarının sağlanması, etkin borç yönetimi gibi } \\
\text { makroekonomik istikrarı destekleyen unsurların iş dünyasını ve } \\
\text { girişimciliği etkilediği gibi ülkenin rekabet gücü performansını arttırmak } \\
\text { açısından da önemli olduğunu açıklamaktadır. }\end{array}$ \\
\hline & Sağlık ve İlköğrenim & $\begin{array}{l}\text { Bu bileşen, işgücü piyasasının sağlam ve sağlıklı bir yapıda olmasının, } \\
\text { rekabet gücü performansı ve verimlilik açısından önem taşıdığını; temel } \\
\text { eğitimin ise çalışanların üretkenliğini arttırdığı ve yeni teknolojilere adapte } \\
\text { olma kabiliyetlerini geliştirdiğini ifade etmektedir. }\end{array}$ \\
\hline \multirow{6}{*}{ 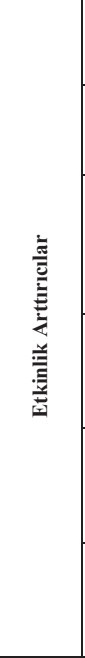 } & Yükseköğrenim ve Eğitim & $\begin{array}{l}\text { Bu bileşen, yükseköğrenim görmüş eğitimli işgücünün varlığı sayesinde } \\
\text { ülkelerin, küreselleşme süreci ile birlikte değişen ekonomik şartlara uyum } \\
\text { sağlayabilme kabiliyetlerinin yükseldiğgini vurgulamaktadır. }\end{array}$ \\
\hline & Mal Piyasası Verimliliği & $\begin{array}{l}\text { Bu bileşen, mal piyasasının sağlıklı olarak işleyebilmesini için uygun bir } \\
\text { rekabet ortamının oluşturulması, piyasa etkinsizliklerinin giderilmesi ve } \\
\text { arz-talep dengesinin uyumlulaştırılması gerektiğini belirtmektedir. }\end{array}$ \\
\hline & İşgücü Piyasası Verimliliği & $\begin{array}{l}\text { Bu bileşen, ücretlerin esnekliği ile çalşsanların verimli oldukları alanda } \\
\text { istihdam edilmelerinin sağlanması suretiyle oluşacak işgücü piyasası } \\
\text { etkinliğini rekabet gücüne yaptığı katkıy içermektedir. İsgücü piyasasında } \\
\text { kadın-erkek eşitliğinin sağlanması da bu bileşenin gözettiği faktörlerden } \\
\text { birisi olmaktadır. }\end{array}$ \\
\hline & $\begin{array}{l}\text { Finansal Piyasaların } \\
\text { Gelişmişliği }\end{array}$ & $\begin{array}{l}\text { Bu bileşen, iç tasarrufların ve dış mali kaynakların risk odaklı şekilde en } \\
\text { etkin olacağı alana yönlendirilmesini ve böylece finansal sistemin } \\
\text { beklenen en yüksek katma değeri sağlayacak şekilde işlemesinin önemine } \\
\text { vurgu yapmaktadır. }\end{array}$ \\
\hline & Teknolojik Hazırlık & $\begin{array}{l}\text { Bu faktör, bir ekonomide endüstriyel verimliliğin arttrilabilmesi için } \\
\text { mevcut teknoloji düzeyinin ne ölçüde sağlandığıı açılamakta; bu } \\
\text { bağlamda toplan verimlilik düzeyinin arttırılmasına yönelik yeni teknoloji } \\
\text { transferinin önemini vurgulamaktadır. }\end{array}$ \\
\hline & Piyasa Büyüklüğü & $\begin{array}{l}\text { Bu bileşen, küreselleşme süreci ile birlikte ulusal piyasalarda korumacılık } \\
\text { uygulamalarının azaltılması ve firmaların uluslar arası düzeyde ekonomik } \\
\text { ilişkilere girişmesinin, ölçek ekonomilerinin oluşmasına firsat tanıdığını ve } \\
\text { böylece verimlilik düzeyini arttırdığını işaret etmektedir. }\end{array}$ \\
\hline \multirow{2}{*}{ 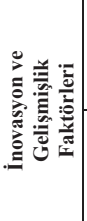 } & İşletme Gelişmişliği & $\begin{array}{l}\text { Bu bileşen, kapsamlı/karmaşık iş süreçlerinin/uygulamalarının daha } \\
\text { yüksek rekabet gücüne erişilebilmesi bakımından önem teşkil ettiğine; } \\
\text { ülkenin iş bağlantılarının yoğunluğu ile firmaların operasyon ve strateji } \\
\text { düzeylerinin kalitesinin de bu süreci desteklediğini açıklamaktadır. }\end{array}$ \\
\hline & İnovasyon & $\begin{array}{l}\text { Bu bileşen, teknolojik buluşların ekonomiler üzerindeki verim-arttırıcı } \\
\text { etkileri ışığında, üretim bilgisi (know-how), işgücü yetenekleri ve çalışma } \\
\text { şartları gibi teknolojik olmayan faktörlerden ziyade teknolojik gelişmişliğe } \\
\text { odaklanmanın önemine vurgu yapmaktadır. }\end{array}$ \\
\hline
\end{tabular}

Kaynak: World Economic Forum, The Global Competitiveness Report 2016-2017, ed., K. Schwab (2016): 36-7. 
Daha sonra, endeks kapsamındaki her bir ülkenin kişi başına düşen milli geliri esas alınmak suretiyle ekonomik gelişme düzeyi belirlenmektedir. $\mathrm{Bu}$ şekilde, faktör-odakl ekonomi, etkinlik-odakl ekonomi, inovasyonodaklı ekonomi ve yapısı itibarıla iki kademe arasında yer alan geçiş ekonomileri olmak üzere üç ana ve iki ara kategori de tasnif edilen ülkeler için, dâhil oldukları kategoriye ait ağırlıklandırma katsayıları kullanılmak ve alt endekslerin aritmetik ortalaması alınmak suretiyle 1 ile 7 arasında (1 en kötü, 7 en iyi) küresel rekabet gücü skoru hesaplanmaktadır. ${ }^{21}$

\section{Tablo 2: Ekonomik Gelişme Düzeylerinin Belirlenmesine Dair Milli Gelir Düzeyleri ve Faktörlerin Ağırlıklandırılması}

\begin{tabular}{|c|c|c|c|c|c|}
\hline & $\begin{array}{c}\text { Düzey 1: } \\
\text { Faktör-Odaklı } \\
\text { Ekonomi }\end{array}$ & $\begin{array}{l}\text { Düzey 1-2: } \\
\text { Geçiş } \\
\text { Ekonomisi }\end{array}$ & $\begin{array}{c}\text { Düzey 2: } \\
\text { Etkinlik-Odaklı } \\
\text { Ekonomi }\end{array}$ & $\begin{array}{c}\text { Düzey 2-3: } \\
\text { Geçiş } \\
\text { Ekonomisi }\end{array}$ & $\begin{array}{c}\text { Düzey 3: } \\
\text { İnovasyon- } \\
\text { Odaklı Ekonomi }\end{array}$ \\
\hline $\begin{array}{l}\text { Kişi Başına Düşen Asgari Milli } \\
\text { Gelir Düzeyleri (US\$) }\end{array}$ & $<2.000$ & $2.000-2.999$ & $3.000-8.999$ & $\begin{array}{l}9.000- \\
17.000\end{array}$ & $>17.000$ \\
\hline $\begin{array}{l}\text { Temel Gereksinimler } \\
\text { Bileşeninin Ağırlıklandırılması }\end{array}$ & $\% 60$ & $\% 40-60$ & $\% 40$ & $\% 20-40$ & $\% 20$ \\
\hline $\begin{array}{l}\text { Etkinlik Arttırıcılar } \\
\text { Bileşeninin Ağırlıklandırılması }\end{array}$ & $\% 35$ & $\% 35-50$ & $\% 50$ & $\% 50$ & $\% 50$ \\
\hline $\begin{array}{l}\text { İnovasyon ve Gelişmişlik } \\
\text { Faktörleri Bileşeninin } \\
\text { Ağırlıklandırılması }\end{array}$ & $\% 5$ & $\% 5-10$ & $\% 10$ & $\% 10-30$ & $\% 30$ \\
\hline
\end{tabular}

Kaynak: World Economic Forum, The Global Competitiveness Report 2016-2017, ed., K. Schwab (2016): 38.

Nihayet bütün bu veriler kullanılmak suretiyle endeks kapsamındaki ülkelerin rekabet gücü performansları belirlenmekte ve iş dünyası açısında en riskli alanlar ile birlikte yıllık olarak Küresel Rekabet Gücü (KRG) Endeksi açıklanmaktadır.

\section{Körfez Ülkelerinde Devlet-Ekonomi İlişskisinin Arka Planı}

Birinci Dünya Savaşı ertesinde belirgin bir hal almakla birlikte, özellikle İkinci Dünya Savaşı sonrası dönemde ABD’nin öncülüğündeki Batı Dünyası ile önderliğini SSCB'nin yaptığı Doğu Bloğu arasında sürekli şekilde

21 World Economic Forum, The Global Competitiveness Report 2016-2017, ed., K. Schwab (2016): 37-8. 
sürdürülen ekonomik, siyasi ve kültürel gerginlik ile sınırlı askeri çatışma atmosferi, literatürde "Soğuk Savaş" olarak tanımlanmakta ve Kapitalist Bat1 Bloğu ile Komünist Doğu Bloğu arasındaki ideolojik savaşın en ateşli dönemine işaret etmektedir. İki kutuplu bu küresel sistem, 1991'de Sovyetler Birliği'nin dağılması sonucu nihayete ermiş, bahse konu sürekli gerginlik ve çatışma ortamının galibi ABD öncülüğündeki Batı Bloğu olmuştur. $\mathrm{Bu}$ durum, dünya genelinde $\mathrm{ABD}$ 'nin küresel egemenliğinin arttığı, ideolojik angajmanın hızlandığı ve uluslararası politikada ABD'nin üstünlüğünün bariz şekilde hissedildiği köklü bir değişimin yaşanmasına sebebiyet vermiştir. ${ }^{22}$

İşte bu hadiseden sonra ortaya çıkan ve baskın bir görünüm arz eden küresel ekonomik sistem, ABD merkezli olarak şekillenen, neo-liberal politikalar perspektifinde oluşturulan ve küreselleşme olgusuyla birlikte ilerleyen iş birliği ve rekabetin ön plana çıktığı serbest piyasa kapitalizmi olmuş, bu durum Doğu Bloğu ülkeleri de dâhil olmak üzere bütün ülkeleri etkisi altına almıştır. Dünya ekonomik sisteminde yaşanan büyük değişim sürecinde, özellikle otoriter yönetimlerin hüküm sürdügü ülkeler, küresel ekonomik sisteme entegre olmak ve bu ilişkinin sürdürülebilir kılınması maksadıyla, ana akım paradigmanın temel gerekliliklerini karşılayacak şekilde büyük bir değişim hamlesinin içerisine girmiş, şok terapi ya da kademeli reform gibi yöntemlerle sisteme entegre (otoriter özelliklerini sürdürseler dahi) rekabetçi bir yapıya evrilmişlerdir. ${ }^{23}$

Devletin rolünün ve ekonomik birimler ile olan ilişkilerin yeniden biçimlendirildiği bu reform süreci, kaynakların etkin, ekonomik ve verimli şekilde kullanılması, hesap verme sorumluluğunun temin edilmesi, siyasal hayata toplumsal katılımın güçlendirilmesi, etkin kaynak dağılımının sağlanması, kamu hizmetlerinin sunumunda kalite anlayışının geliştirilmesi ile taleplere hizla cevap verilebilmesi, diğer yandan mal ve hizmetlerin

22 Tayyar Arı ve Ferhat Pirinççi, "Soğuk Savaş Sonrasında ABD’nin Balkan Politikası," Alternatif Politika 3 no. 1 (2011): 2-3; Ferhat Pirinççi, "Soğuk Savaş Sonrasında ABD'nin Orta Asya Politikası: Beklentiler ve Gerçeklikler," Ankara Üniversitesi Siyasal Bilgiler Fakültesi Dergisi 63, no. 1 (2008): 208.

23 Steven Levitsky ve Lucan A. Way, "The Rise of Competitive Authoritarianism," Journal of Democracy 13 no. 2 (2002): 51-2; Özge Özkoç, “Türkiye'nin Kuzey Afrika'ya Yönelik Politikası: Bir Modelin Çöküşü,” Ankara Üniversitesi Siyasal Bilgiler Fakültesi Dergisi 72 no. 1 (2017): 80; Savaş Çevik ve Erol Turan, "Devletin Kurumsal Dönüşümü: Orta Asya Cumhuriyetleri Perspektifinden," Bilig no. 41 (2007): 209-11. 
doğrudan sunumu ile değil ve fakat bunlara erişimin kolaylaştırılmasını sağlayan mekanizmalar ile sürdürülebilir ekonomik performansın gerçekleştirilmesini temin eden etkin bir devlet modeli yapılanması öngörülmüştür. $^{24}$

Devleti küçültüp, karşıl1klı ve çok yönlü komplike ilişkiler öngören piyasa ekonomisi odaklı bu reform süreci, Sovyetler Birliği ile ekonomik ve siyasi anlamda bütünleşmiş ülkeler ile Soğuk Savaş sonrası dönemde ABD'nin hegemonik bir güç haline gelmesi ve bunun sürdürülebilirliği için gerekli finansal, politik, askeri ve coğrafi koşulların yerine getirilmesi noktasında önem arz eden ülkelerde dönüşümü zorunlu ve gerekli kılmıştır. Ancak, neo-liberal felsefeden beslenen ve iktisadi anlamda piyasa ekonomisini siyasi anlamda ise demokratik yönetim anlayışını ön plana çıkaran etkin bir devlet modeli öngörüsünün, özellikle jeostratejik önemi yüksek ülkelerde teşkil etmesi durumunda bir kontrol sorununa yol açı açmayacağı hususu dikkatle takip edilmiş, işbu ülkelerde küresel ekonomik sisteme entegre bir devlet modeli inşa etmenin gerekliliugi, klasik kapitalist ülkelerden farklı bir modelin ortaya çımasına da sebebiyet vermiştir. Bu durum, ekonomik hayatta ulusal ekonomi için kilit rolü bulunan sektörlerin devlet mülkiyetli şirketler ve ulusal varlık fonları gibi çeşitli araçlar ile kontrol altında tutulduğu ve fakat bilfiil ekonomik aktivitelerin tamamının kontrol altına alınmadığı, küresel ekonomik sistemle barışık/tümleşik, buna karşılık devletin ve politikacıların ekonomik hayattaki etkilerinin azalmadığı otoriter yönetimlerin iktidar gücünü sürdürdükleri, yeni nesil kapitalist ${ }^{25}$ ülkeler şeklinde dizayn edilmeleriyle yenidünya düzeni içerisinde bir konum elde etmişlerdir. ${ }^{26}$

Körfez İş birliği Teşkilatı üyesi ülkeler olan Bahreyn, Birleşik Arap Emirlikleri, Katar, Kuveyt, Suudi Arabistan ve Umman İkinci Dünya Savaş1 ertesinde bağımsızlıklarını kazanmış otoriter-baskıcı monarşiler olarak bilinmektedirler. Bir taraftan enerji güvenliği ihtiyacı, diğer taraftan ise

24 World Bank, World Development Report 1997: The State in a Changing World (Washington D.C., 1997): 29-38; Ajay Chhibber, "The State in a Changing World," Finance \& Development (1997): 17-20.

25 Yeni devlet kapitalizmi, her ülkede de farklı varyasyonlarla uygulanan ancak politikacıların neo-liberal kapitalizme göre daha fazla güç sahibi olduğu, küresel iktisadi düzene bütünleşmiş bir yapıdır. Detaylı bilgi için bkz. "The Rise of State Capitalism," The Economist, 26.06.2012, https://www.economist.com/node/21543160.

26 Orhan Şimşek, Küreselleşme ve Yeni Devlet Kapitalizminin Yükselişi (Ankara: Türk Metal Sendikası Araştırma ve Eğitim Merkezi Yayınları, 2017): 71-9. 
İran'ın politik etkinliğini arttırmaya matuf yayılmacı siyaseti karşısında 1981 yılında Körfez Arap Ülkeleri İş birliği Konseyi adı altında bir araya gelen mezkûr ülkeler, stratejik önem haiz coğrafi konumlarının sağladığ avantajlar ve sahip oldukları zengin doğal kaynak rezervlerinin ihracına dayalı ekonomik yapıları sayesinde hızlı bir sermaye birikim sürecine sahne olmuşlardır.

Körfez İş birliği Teşkilatı üyesi ülkelerin bahse konu sosyo-politik yapıla$\mathrm{r}$, literatürde rantiyer devlet olarak adlandırılmaktadır. ${ }^{27}$ Rantiyer devlet teorisi, Mahdavy tarafindan, 1970'li y1llarda İran'ın sosyo-politik yapısını açıklamak maksadıyla yayımladığı öncü çalışması "Rantiyeci Devletlerde Ekonomik Gelişmenin Yapısı ve Problemleri: İran Örneği" ${ }^{28}$ adlı makalesinde, gelirlerinin büyük kısmı düzenli diş kaynaklardan elde eden devletler şeklinde tanımlanmıştır. Bilahare Beblawi, ${ }^{29}$ Luciani $^{30}$ ve Ross' un ${ }^{31}$ katkılarıyla geliştirilerek neredeyse bütün Ortadoğu ülkeleri için kullanı$\operatorname{lan}^{32}$ mezkûr kavram, günümüzde doğal kaynaklardan yüksek rant geliri elde eden Ortadoğu dışındaki diğer ülkeler için de sıklıkla kullanılmakta ve gerek iktisat gerekse siyaset bilimi ve uluslararası ilişkiler literatürlerinde kabul görmektedir. ${ }^{33}$

27 Ortadoğu ülkelerinde rantiyer yapıların oluşmasının başat faktörü, sahip olunan yüksek miktarlarda doğal kaynakların varlığıdır. Dünya petrol rezervlerinin yaklaşık $2 / 3$ 'üne sahip olan Ortadoğu bölgesi, dünya petrol üretiminin yaklaşı \%30'unu yapmakta ve sadece \%10'unu tüketmektedir. Doğalgaz için de benzer bir durum söz konusudur. $\mathrm{Bu}$ göstergeler Ortadoğu bölgesinin net petrol ihracatçısı olduğunu göstermektedir ki, bu da oldukça yüksek enerji gelirleri demektir. Detaylı istatistikî bilgi için bkz. BP, Statistical Review of World Energy - 2016 Update, 2017.

28 Hossein Mahdavy, "The Patterns and Problems of Economic Development in Rentier States: The Case of Iran," ed. M. A. Cook, Studies in the Economic History of the Middle East-From the Rise of Islam to the Present Day (Oxford: Oxford University Press, 1970): 428-67.

29 Hazem Beblawi, "The Rentier State in the Arab World," The Arab State, ed., Giacomo Luciani (London: Routledge, 1990): 85-98.

30 Giacomo Luciani, "Allocation vs. Production States: A Theoretical Framework," The Arab State, ed., Giacomo Luciani (London: Routledge, 1990): 65-84.

31 Michael Ross, “Does Oil Hinder Democracy?, World Politics 53 no. 3 (2011): 32561.

32 Lisa Anderson, "The State in the Middle East and North Africa," Comperative Politics 20 no. 1 (1987): 9.

33 Kavramın uluslararası ilişkiler boyutları hakkında detaylı bilgi için bkz. Engin Sune ve Ali Murat Özdemir, "Rantçı Devlet Yazını Üzerine Deneme," Uluslararası İlişkiler, Cilt: 9, Sayı: 35, 2012, 3-31; siyaset bilimi literatüründeki yeri ve gelişimine ilişkin detaylı bilgi için bkz. Lisa Anderson, "The State in the Middle East and North Africa," Comperative Politics, Cilt: 20, Sayı: 1, 1987, 1-18; kavramın ekonomi literatüründeki 
Tablo 3: Rantiyer Devlet Teorisinin (RDT) Gelişim Aşamaları

\begin{tabular}{|c|c|c|c|}
\hline Aşama & $\begin{array}{l}\text { Temel } \\
\text { Karakteristikler }\end{array}$ & $\begin{array}{l}\text { İlgili } \\
\text { Araştırmacı }\end{array}$ & $\begin{array}{l}\text { Zaman } \\
\text { Dilimleri }\end{array}$ \\
\hline $\begin{array}{l}\text { Birinci Aşama: } \\
\text { Klasik RDT }\end{array}$ & $\begin{array}{l}\text { Devlet, gelirlerinin büyük bir çoğunluğunu dış kaynaklardan elde } \\
\text { etmektedir. } \\
\text { Devlet, vatandaşlarından vergi toplamak gibi bir uygulaması yoktur, yüksek } \\
\text { sosyal transfer harcamaları sayesinde 'dağıtıcı' nitelik taşır. } \\
\text { Devlet, rant gelirleri üzerindeki tasarruf hususunda toplumdan bağımsız bir } \\
\text { şekilde hareket eder. } \\
\text { Devlet ekonomik ya da kalkınma programı yapmaz. } \\
\text { Devlette yolsuzluk ve savurganlı/israf yüksek seviyelerdedir. } \\
\text { Elit kesimin politik ilişkileri neo-patrimonyal ilişkiler doğrultusunda } \\
\text { yürütülmekte, aynı zamanda patrimonyal ilişkiler de rantiyer sistemden } \\
\text { beslenmektedir. }\end{array}$ & $\begin{array}{l}\text { Mahdavy } \\
(1970), \\
\text { Beblawi (1987; } \\
\text { 1990), } \\
\text { Luciani (1990) }\end{array}$ & $\begin{array}{l}\text {-İran (1960-70'ler) } \\
\text {-Körfez Arap } \\
\text { Ülkeleri } \\
\text { (1950-80'ler) } \\
\text {-Irak (1960-80'ler) } \\
\text {-Cezayir gibi Diğer } \\
\text { Sanayi } \\
\text { Ülkeleri (1960- } \\
\text { 90'lar) } \\
\text {-Misır (1960-90'lar) } \\
\text {-Ürdün (1970- } \\
\text { 80'ler) }\end{array}$ \\
\hline $\begin{array}{l}\text { İkinci Aşama: } \\
\text { Uzmanlaşmış } \\
\text { RDT }\end{array}$ & $\begin{array}{l}\text { Uzmanlaşmış RDT } \\
\text { (Klasik RDT'nin biraz daha ayrıntılı ve gelişmiş biçimi) } \\
\text { Devlet yine 'dağıtıcı' özellik taşır fakat bazı vergi uygulamaları görülür. } \\
\text { Devlet, rant gelirleri üzerindeki tasarruf hususunda toplumdan görece } \\
\text { bağımsızdır. } \\
\text { Devletin bir ekonomi politikası vardır. } \\
\text { Devlet mikro ve makroekonomik ilişkilerde rol sahibidir. }\end{array}$ & $\begin{array}{l}\text { Uzmanlaşmıs } \\
\text { RDT } \\
\text { Crystal (1990), } \\
\text { Chaudhry } \\
\text { (1997), } \\
\text { Hertog (2010), } \\
\text { Davidson (2008; } \\
\text { 2009) }\end{array}$ & $\begin{array}{l}\text {-Bir veya birkaç } \\
\text { Körfez Arap Ülkesi, } \\
\text { (Genellikle } \\
\text { 1980'ler,1990'lar } \\
\text { veya 2000'ler) } \\
\text {-Bazı çalışmalara } \\
\text { göre ise } \\
\text { Suudi Arabistan ve } \\
\text { Yemen } \\
\text { (1980'ler) }\end{array}$ \\
\hline $\begin{array}{l}\text { Koşullu } \\
\text { RDT }\end{array}$ & $\begin{array}{l}\text { Koşullu RDT } \\
\text { (Klasik RDT'nin yeni bakış açılarına açık olmasını gerektiğini savunan } \\
\text { şekli) } \\
\text { Devlet, iş dünyası, kamu mali yönetimi, ekonomi, uluslararası ilişkiler ve } \\
\text { benzeri alanlarda diğer teorilere açı olmalıdır. } \\
\text { Politika yapımında devlet-toplum bağı nispeten daha fazladır. }\end{array}$ & $\begin{array}{l}\text { Koşullu RDT } \\
\text { Herb (1999), } \\
\text { Al-Rasheed } \\
\text { (2010), } \\
\text { Jones (2010), } \\
\text { Foley (2010), } \\
\text { Schwarz (2008) }\end{array}$ & $\begin{array}{l}\text {-Birçok çalışmaya } \\
\text { göre } \\
\text { Ürdün ve Fas gibi } \\
\text { diğer } \\
\text { monarşiler veya } \\
\text { zaman } \\
\text { zaman da diğerleri }\end{array}$ \\
\hline $\begin{array}{l}\text { Üçüncü } \\
\text { Aşama: } \\
\text { Geç Dönem } \\
\text { RDT }\end{array}$ & $\begin{array}{l}\text { Devlet, kalkınma ve reform hususlarındaki toplum baskısı ile küreselleşme } \\
\text { ve 'kaynakların lanet'i hakkındaki tecrübelerinin getirdiği olgunluk } \\
\text { sayesinde daha sorumlu, küresel ilişkilere sahip ve stratejik hareket eden bir } \\
\text { yapıya evrilmiştir. } \\
\text { Fakat RDT'nin dinamiğini oluşturan ve dönemsel bir karakteristik } \\
\text { taşımadığı anlaşılan devlet-toplum ilişkileri daha da gelişmiş bir biçimiyle } \\
\text { sürdürülmektedir. }\end{array}$ & $\begin{array}{l}\text { Moore (2004), } \\
\text { Hertok (2010) } \\
\text { Davidson (2008; } \\
\text { 2009), } \\
\text { Hvidt (2009; } \\
\text { 2011; ve } \\
\text { diğerleri }\end{array}$ & $\begin{array}{l}\text { Körfez Arap } \\
\text { Ülkeleri olan } \\
\text { Bahreyn, BAE, } \\
\text { Kuveyt, Katar, } \\
\text { Suudi Arabistan, } \\
\text { Umman } \\
\text { (1990'lardan } \\
\text { günümüze) }\end{array}$ \\
\hline
\end{tabular}

Kaynak: Matthew Gray, "A Theory of 'Late Rentierism' in the Arab States of the Gulf," CIRS Occasional Paper no. 7 (2011): 24.

Bu bağlamda Gray, Tablo 3'ten de izlenebileceği üzere, temel olarak yüksek dış gelirler, vergi yükünün düşüklügü, transfer harcamalarının genişli$\breve{g} i$, etkin olmayan ve yolsuz bürokrasi, karmaşık patrimonyal ilişkiler gibi özellikleri barındıran rantiyeci devlet teorisinin, Ortadoğu bölgesi özelinde, genel olarak üç aşamalı bir dönüşüm süreci izlediğini belirtmektedir.

gelişimini GCC üyesi ülkeler özelinde açıklayan bir çalışma için bkz. Matthew Gray, "A Theory of 'Late Rentierism' in the Arab States of the Gulf," CIRS Occasional Paper no. 7 (2011). 
Bu dönemde Körfez Arap ülkelerinin de özet olarak, 1950-1980 yılları arasında klasik rantiyer devlet, 1980-2000 yılları arasında uzmanlaşmış rantiyer devlet ve 90'lı yılların sonu ile 2000'li y1llarda ise geç dönem rantiyer devlet aşamalarından geçtikleri görülmektedir.

1950-1980 dönemini klasik rantiyer devlet perspektifinden bak1lacak olursa, elde edilen yüksek enerji gelirlerinin önemli bir kısmı yönetime hâkim olanların elinde kalırken, kalan kısmı da düşük nüfus-yüksek gelir ilişsisi bağlamında bir taraftan fiziki ve kurumsal altyapının modernizasyonu, diğer taraftan ise transfer harcamaları şeklinde doğrudan halka dağıtılmakta, kamu finansmanı için vergi talep edilmez iken vergi-temsil dengesi gereği halkın yönetime katılması da mümkün olmamaktadır. Devlet-toplum arasındaki işbu zımni sözleşmenin ortaya koyduğu rantiyer yapı ilk bakışta hem yönetici monarklar hem de halk açısından oldukça cazip görünmekte ve mevcut geleneksel toplumsal ilişkiler formunun devamı için irade gösterilmektedir. Öte yandan rantiyer devlet, enerji fiyatlarındaki konjonktürel dalgalanmaların enerji gelirleri üzerindeki negatif değiştirici etkisi, enerjimerkezli bir yapıya hapsolması nedeniyle sektörel çeşitliliğin bulunmadığ katı/esnek olmayan bir ekonomik yapının mevcudiyeti, politik sistemin katılımcı nitelik taşımaması neticesinde halkın sürekli olarak siyasal hakların talep etme potansiyelinin bulunması gibi handikapları da her daim bünyesinde barındırmaktadır. ${ }^{34}$

Bahse konu süreçte ekonomik anlamda enerji-merkezli ekonomik aktivitenin sebep olduğu Hollanda hastalı̆ ${ }_{l}{ }^{35}$ doğal kaynaklar üzerindeki kamu mülkiyetinin neden olduğu dişlama etkisi, bu özellikler dolayısıyla

34 Simon Murden, "Politik Ekonomi - Modernleşmeden Küreselleşmeye," Ortadoğu Tarihi Dini, Siyasi, Kültürel ve Ekonomik Perspektiften, ed. Youssef M. Choueiri, çev. Fethi Aytuna (İstanbul: İnkılâp Yayınları, 2011): 450-1; Sadık Ünay, Kalkınmacı Modernlik - Küresel Ekonomi Politik ve Türkiye (İstanbul: Küre Yayınları, 2013): 317-8; Paul Stevens, "Petrol ve Kalkınma," Ortadoğu Tarihi Dini, Siyasi, Kültürel ve Ekonomik Perspektiften, ed. Youssef M. Choueiri, çev. Fethi Aytuna (İstanbul: İnkılâp Yayınlar1, 2011): 496.

35 "Hollanda Hastalığı" kavramsal olarak, yeni bir doğal kaynağın keşfedilmesi ve ihracı ile ülkeye yüksek miktarda döviz girişi olması gibi bir nedene dayalı olarak, ülke parasının aşırı değerlenmesi ve ülkenin üretim yapısının değişmesi, buna bağlı olarak özellikle imalat sanayinin rekabet gücünün zayıflaması nedeniyle üretimin ve ihracatın azalması, ithalatın artması olarak tanımlanabilir. Konu hakkında detaylı bilgi için bkz. Sarvar Gurbanov, Hollanda Hastalığı: Teori ve Ülke Örnekleri (İstanbul: Akis Kitap, 2012): 13. 
yolsuzluğu meşru gören ayrıcalıklı bir kesimin oluşması ve mevcut yönetim tarzının yerleşik hale gelmesi ile birlikte klasik rantiyer ilişki biçimi Körfez Arap ülkelerinde kurumsallaşmıştır. Nitekim bu durum,1980'li yılların başından itibaren hızla azalan enerji fiyatları karşısında yönetimleri hem sosyo-ekonomik hem de politik arenada oldukça müşkül bir durumda bırakmıştır. Şöyle ki düşen kamu gelirleri nedeniyle kısılan transfer harcamalarına karşılık, bir taraftan alternatif ekonomi politikaları ve reform ajandaları geliştirilememiş, diğer taraftan da vazgeçilen politik haklar talep edilmeye başlanmıştır. Yüksek düzeye erişen emtia fonlarının/rezervlerinin topluma aktarılması ve güçlü ordular sayesinde sivil inisiyatif potansiyelinin törpülenmesi suretiyle iktidar ilişkilerinin devamı sağlanmış ise de bir taraftan Körfez Arap ülkelerinin mevcut yönetim yapılarının meşruiyetlerinin sorgulanması engellenememiş; diğer taraftan ise anılan bu tecrübeler, rantiyer ilişki biçimlerinin dönüştürülmesi konusunda öğretici olmuştur. ${ }^{36}$

1990'lı yıllar ile birlikte yaşanan diş borç krizleri ile birlikte, küresel hegemonik sistemin sürükleyici aktörleri olan IMF, Dünya Bankası ve Dünya Ticaret Örgütü gibi uluslararası ekonomik kuruluşlar, bir taraftan devletin ekonomi içerisindeki rolünün küçültülmesine matuf özelleştirme ve deregülasyon ajandaları oluşturulmasını, diğer taraftan ise siyasal katılımc1lığın arttırılması, hukuk devleti anlayışının içselleştirilmesi, bürokratik etkinliğin sağlanması hususlarına yönelik reform reçeteleri tavsiye etmeye başlamışlardır. Bu süreçte Körfez ülkeleri açısından, özellikle dış ticari faaliyetler üzerinde kısıtlayıcı düzenlemelerin gevşetilmesi bağlamında, vergi hukuku, iş/çalışma mevzuatı, telif/patent haklarına dair reformları da içeren Dünya Ticaret Örgütü'nün tavsiyeleri belirleyici olmuştur. Böylece, artan nüfusa karşı1lı yeni iş imkânlarının oluşturulması, toplum yararını da gözetecek şekilde ekonomik ilişkilerin daha sürdürülebilir bir yapıya kavuşturulması amaçlanmıştır. ${ }^{37}$

Ancak Dünya Bankası'nın 1988-2008 dönemini kapsayan özelleştirme istatistikleri ${ }^{38}$ incelendiğinde Ortadoğu bölgesinde kamu işletmelerini direkt

36 Ünay, Kalkınmacı Modernlik - Küresel Ekonomi Politik ve Türkiye, 318-9; Stevens, "Petrol," 497-501.

37 Murden, "Politik," 456-8.

38 World Bank, Privatization Database (1990-2008), 22.07.2017, http://data.worldbank. org/datacatalog / privatization database. 
satış, halka arz ve benzeri metotlar dâhilinde kamu kontrolünden çıkarmak hususunda Misır, Tunus ve Fas'ın başat rolü oynadığı, Körfez Arap ülkele$\operatorname{rinin}^{39}$ ise kapsamlı ve planlı bir özelleştirme gündemlerinin bulunmadığ görülmektedir. ${ }^{40}$ Bununla birlikte, yine Dünya Bankası tarafından üretilen Dünya Yönetişim Göstergeleri'nin işaret ettiği üzere sosyal ve siyasal kurumlara dair kayda değer gelişmeler gözlemlenmeyen ${ }^{41}$ Körfez Arap ülkeleri, kısmi deregülasyon politikaları, finans altyapısının kuvvetlendirilmesi, yatırım ve ticaret ikliminin iyileştirilmesi gibi piyasayı teşvik edici uygulamalar ile birlikte, ekonomik yönü itibarıyla kaynakların laneti hakkındaki tecrübelerinin getirdiği olgunluk sayesinde daha sorumlu, küresel ilişkilere sahip ve stratejik hareket eden bir yapıya evrilerek geç dönem rantiyer devlet ${ }^{42}$ aşamasına geçmektedirler. ${ }^{43}$

\section{Körfez Ülkelerinde Rekabet Gücü Performansının Ekonomi Politiği}

Küreselleşme olgusuyla birlikte ilerleyen, bölgesel ve global iş birliği ve rekabetin ön plana çıktığı serbest piyasa kapitalizmi olarak da adlandırılan bu yeni dünya sisteminde, ülkedeki yaşam standartlarını yükseltmek ve vatandaşlarının refah artışını sağlamak devletlerin öncelikli vazifesi halini almıştır. Bunun sağlanmasındaki temel yol ise ülkede verimlilik artışının temin edilmesi suretiyle daha yüksek katma değer üretebilme kabiliyeti elde edilmesi, diğer bir ifade ile ülkenin rekabet gücünün arttırılması olarak karşımıza çıkmaktadır. Söz konusu husus, kişisel seçim, mübadele serbestliği, piyasa/pazara giriş, ve rekabet özgürlüğü ile özel mülkiyet gü-

39 Körfez Arap ülkelerindeki özelleştirme uygulamalarına ilişkin kısa birer özet için bkz. Jamal Saghir, "Infrastructure Privatization in the MENA Region," State StateOwned Enterprises in the Middle East and North Africa-Privatization, Performance and Reform (London: Routledge, 2001): 89-127.

40 Adam Hanieh, İsyanın Kökenleri - Kapitalizmin Ortadoğu'daki Sorunları, çev. Ali Toprak (Ankara: Notabene Yayınlar1, 2015): 92-6; Murden, "Politik," 456-8.

41 World Bank, World Governance Indicators 1996-2015, 22.07.2017, http://info. worldbank.org/governance/ wgi/\#home.

42 Bu kavrama karşılık; "Petro-kapitalist Devlet," "Devletin Yönettiği Tekelci Kapitalizm," "Bürokratik Kolektivizm," "Totaliter Devlet Kapitalizmi” gibi çeşitli kavramlar kullanılmaktadır. Detaylı bilgi için bkz. Şimşek, Küreselleşme ve Yeni Devlet Kapitalizminin Yükselişi, 71-3.

43 John Waterbury ve Diğerleri, A Political Economy of the Middle East (USA: Westview Press, Fourth Edition, 2015): 321-2; Gray, “A Theory," 18-24. 
venliğinin oluşturulması, kurumlar/birimler/orgazisyonlar arası dayanışma ve uzmanlaşmanın güçlendirilmesi gibi hususların temin edilmesi ile sağlanabilecektir. ${ }^{44}$

Esasen rekabet gücünü etkileyen ve belirleyen çok sayıda faktör olması dolayısıyla, rekabet türlerine de bağlı olarak, rekabet gücü göstergeleri/endeksleri farklılıklar ihtiva etmektedir. Diğer yandan, rekabet gücünü temsil edebilecek faktörlerin başında verimlilik geldiği hususu ise genel kabul görmektedir. Bununla birlikte, bir ülkenin rekabet gücünü tek boyutlu bir gösterge ile ölçen çalışmalar olduğu gibi birden fazla boyut ile hatta birkaç yüz göstergeyi birleştirilerek kompozit bir yöntemle ölçen çalışmaların da bulunduğunu ifade etmek gerekmektedir. ${ }^{45}$

Çalışma kapsamında, daha önce de ifade edildiği üzere, ülkelerin rekabet gücü performansını anlamlandırmak/yorumlamak için ideal bir altyapı sunan ve ekonomik performans ile rekabet gücüne her birinin çok önemli ve belirgin katkıları bulunduğu değerlendirilen temel gereksinimler (TG), etkinlik artırıcılar (EA) ve inovasyon ve gelişmişlik faktörleri (IGF) bileşenlerinden oluşan Küresel Rekabet Gücü (KRG)Endeksi verilerine başvurulacak olup, işbu endeks bağlamında rekabet edebilirlik; bir ülkenin üretkenliğini belirleyen bir dizi kurum, politika ve faktör olarak tanımlanmakla, ülkenin üretkenlik seviyesi ise ekonominin ulaşabileceği refah seviyesi olarak tanımlanmış bulunmaktadır. ${ }^{46}$

Körfez ülkeleri de vatandaşlarının refahını ve yaşam standartlarını yükseltmek bununla birlikte yeni global sisteme entegre yapılarını sürdürülebilir kılmak ve hem bölgesel hem de küresel anlamda rekabet güçlerini arttırmak maksadıyla yatırım ortamının iyileştirilmesi ve iş/girişim prosedürlerinin basitleştirilmesi gibi düzenlemelere odaklanarak özellikle bankacılık ve finans, turizm ve diğer bazı hizmet sektörlerinde yoğun reform girişimlerinde bulunmaktadırlar. Bu noktada, adı geçen ülkelerin, uzmanlaşmış rantiyer devlet aşamasından geç dönem rantiyer devlet düzeyine geçiş sürecinde bahse konu kurumsal dönüşüm çabalarının küresel rekabet gücü performanslarına etkilerinin hazırlanan tablolardan da yararlanmak suretiyle analizi cihetine gidilecektir. Öncelikle, Körfez ülkelerinin küresel rekabet gücü performanslarının gelişim trendleri analize konu edilecek

44 S. M. Gökmenoğlu ve Diğerleri, "Ulusal," 37; Taşıran ve Özoğlu, Kuzey Kıbrıs 20162017 Rekabet Edebilirlik Raporu, 4.

45 Muhittin Adıgüzel, "Küresel Rekabet Gücünün Ölçülmesi ve Türkiye Bağlamında Bir Değerlendirme, Akademik Bakış no. 37 (2013): 2-7.

46 Taşıran ve Özoğlu, Kuzey Kıbrıs 2016-2017 Rekabet Edebilirlik Raporu, 31. 
akabinde ise küresel rekabet gücü unsurları (alt bileşenler) bağlamında yapılacak bir değerlendirme ile işbu ülkelerin mevcut performanslarının analizi, temel sorunların tespiti ve çözüm önerilerine dair çıkarsamalarda bulunulacaktır.

2008-2017 döneminde Körfez ülkelerinin küresel rekabet skorlarının birbirinden farklı görünüm arz ettikleri ve fakat genel olarak küçük inişler-ç1kışlar sergileyen bir trende sahip oldukları anlaşılmaktadır. Katar'ın 2008 yılında 4,8 olan KRG Endeksi puanının 0,4'lük artışla 5,2'ye, aynı dönemde Suudi Arabistan'ın da 4,7 olan skorunun ise 0,1 puanlık artış ile 4,8'e yükseldiği Tablo 4'ten izlenmektedir. Bu süreçte Bahreyn, Kuveyt ve Umman'ın skorlarında herhangi bir artış sağlanamamış, hatta düşüşler gözlenmiştir. 2008 yılı puanlarına göre bölge içi sıralama; Katar-Suudi Arabistan-BAE-Kuveyt-Bahreyn ve Umman şeklinde iken, son yıl puanlarına göre sıralama BAE-Katar-Suudi Arabistan-Kuveyt-Bahreyn ve Umman şeklinde değişmiştir.

\section{Tablo 4: Körfez Ülkelerinin Küresel Rekabet Gücü Performansları} (2008-2017)

\begin{tabular}{|c|c|c|c|c|c|c|c|c|}
\hline \multicolumn{5}{|c|}{ Bahreyn } & \multicolumn{4}{|c|}{ Birleșik Arap Emirlikleri } \\
\hline & \multicolumn{2}{|c|}{ 2008-2009 } & \multicolumn{2}{|c|}{ 2016-2017 } & \multicolumn{2}{|c|}{$2008-2009$} & \multicolumn{2}{|c|}{ 2016-2017 } \\
\hline & Sira & Skor & Sira & Skor & Sira & Skor & Sira & Skor \\
\hline KRG & 37 & 4,6 & 48 & 4,5 & 31 & 4,7 & 16 & 5,3 \\
\hline$T G$ & 28 & 5,3 & 40 & 5,0 & 17 & 5,7 & 11 & 5,9 \\
\hline$E A$ & 46 & 4,3 & 40 & 4,5 & 29 & 4,6 & 15 & 5,2 \\
\hline$\dot{I} G$ & 54 & 3,8 & 42 & 4,0 & 38 & 4,1 & 21 & 4,9 \\
\hline \multicolumn{5}{|c|}{ Katar } & \multicolumn{4}{|c|}{ Kuveyt } \\
\hline & \multicolumn{2}{|c|}{$2008-2009$} & \multicolumn{2}{|c|}{ 2016-2017 } & \multicolumn{2}{|c|}{$2008-2009$} & \multicolumn{2}{|c|}{ 2016-2017 } \\
\hline & Sira & Skor & Sira & Skor & Sira & Skor & Sira & Skor \\
\hline KRG & 26 & 4,8 & 18 & 5,2 & 35 & 4,6 & 38 & 4,5 \\
\hline$T G$ & 21 & 5,5 & 5 & 6.1 & 39 & 5,1 & 36 & 5.1 \\
\hline$E A$ & 31 & 4,5 & 21 & 5,0 & 52 & 4,2 & 70 & 4,1 \\
\hline$\dot{I} G$ & 35 & 4,1 & 18 & 5,0 & 52 & 3,8 & 79 & 3,5 \\
\hline \multicolumn{5}{|c|}{ Suudi Arabistan } & \multicolumn{4}{|c|}{ Umman } \\
\hline & \multicolumn{2}{|c|}{$2008-2009$} & \multicolumn{2}{|c|}{ 2016-2017 } & \multicolumn{2}{|c|}{$2008-2009$} & \multicolumn{2}{|c|}{ 2016-2017 } \\
\hline & Sira & Skor & Sira & Skor & Sira & Skor & Sira & Skor \\
\hline KRG & 27 & 4,7 & 29 & 4,8 & 38 & 4,6 & 66 & 4,3 \\
\hline$T G$ & 34 & 5,2 & 32 & 5,2 & 31 & 5,2 & 42 & 5,0 \\
\hline$E A$ & 45 & 4,3 & 33 & 4,7 & 61 & 4,1 & 63 & 4,2 \\
\hline$\dot{I} G$ & 37 & 4,1 & 36 & 4,1 & 48 & 3,9 & 69 & 3,6 \\
\hline
\end{tabular}

Not: KRG-Küresel Rekabet Gücü Endeksi Ortalamas1; TG-Temel Gereksinimler; EAEtkinlik Artırıcılar; İGF-İnovasyon ve Gelişmişlik Faktörleri.

Kaynak: World Economic Forum, The Global Competitiveness Report 2008-2009, ed., Michael E. Porter ve Klaus Schwab (2008); World Economic Forum, The Global Competitiveness Report 2016- 2017, ed., Klaus Schwab (2016). 
Bu dönemde Birleşik Arap Emirlikleri' nin 4,7 olan KRG Endeksi skorunun 0,6 puanlık artışla 5,3'e yükseldiği ve dünya genelinde 16'ncı sırada bulunduğu, Körfez ülkeleri içerisinde ise en yüksek rekabetçilik performansına sahip ülke konumuna geldiği görülmektedir. Bölge ülkelerine kıyasla daha yüksek sanayileşme oranına sahip olan, imalat, turizm başta olmak üzere diğer hizmet sektörlerindeki gelişim dolayısıyla enerji-odaklı ekonomik yapısını kısmen de olsan dönüştürebilen Birleşik Arap Emirlikleri’nin, 2010 y1lında Dubai'de faaliyete başlayan yüksek kapasiteli modern ticaret limanı ile dış ticaret faaliyetlerinin hız kazanmasını temin etmek, 20102013 döneminde şirket kuruluş prosedürlerini basitleştirip asgari sermaye koşulunu kaldırarak yabancı yatırımcıları teşvik etmek, 2014-2015 yıllarında sözleşmelerin uygulanabilirliği ve mülkiyet hakları güvencesine dair kolaylaştırıcı düzenlemeler yapmak ve bazı işlem harçlarını kaldırmak suretiyle, küresel rekabet gücü anlamında en büyük gelişimi sağladığg söylenebilmektedir. ${ }^{47}$

Tablo 4'de yer alan verilerden de izlenebileceği üzere, 2008-2017 döneminde temel gereksinimler alanında en büyük gelişimi, ekonomik büyümeyi sosyal ve insani kalkınma ile harmanlamayı ve kaynakların sürdürülebilirliğini temin edebilecek çeşitlendirilmiş bir ekonomik yapı inşa etmeyi amaçlayan 2030 Ulusal Vizyonu kapsamında turizmin gelişmesine de destek olacak ulaşım/taşımacılık ile inşaat sektöründe yüksek oranlı büyüme rakamlarına erişmek, ticari faaliyetlere ilişkin iş ve işlemlerin Ticaret Odas1 bünyesinde yürütülmesine olanak sağlayacak şekilde entegre etmek, iş yapma/girişim başlatma prosedürlerini basitleştirmek, daha etkin bir kredi mekanizması oluşturmak, diş ticarete dair belgelerin elektronik ortamda sunulmalarına imkan sağlayarak sınır ötesi ticari faaliyetler hızlandırmak, kurumlar vergisi ödeme prosedürlerini basitleştirmek ve benzeri çok say1da reform gerçekleştirme suretiyle 5,5 olan puanını 6,1 seviyesine çıkartarak dünya sıralamasında 5 'inciliğe yükselen Katar göstermiş bulunmaktadır. Bu dönemde Katar'ın, özellikle makroekonomik istikrar ve altyap alt bileşenlerinde önemli bir gelişim trendi yakaladığını belirtmekte fayda

47 World Economic Forum. The Global Competitiveness Report 2008-2009, ed., Michael E. Porter ve Klaus Schwab (2008); World Economic Forum. The Global Competitiveness Report 2016-2017, ed. Klaus Schwab (2016); World Bank, Doing Business 2010, (Washington DC, 2009): 12, 18, 50-51; World Bank, Doing Business 2012 (Washington DC, 2012): 75; World Bank, Doing Business 2015 (Washington DC, 2014): 21, 22, 29, 35, 41, 58, 65, 78 . 
vardır. İşbu bileşen bağlamında artış sağlayan bir diğer ülke ise kara, deniz ve hava ulaşım altyapısını ciddi ölçüde yenileyen ve bu bağlamda puanını 0,2 arttırarak 5,9'a çıkaran Birleşik Arap Emirlikleri olmuştur. Kuveyt ve Suudi Arabistan'da ise herhangi bir gelişim gerçekleşmemiş ve puanları aynı düzeyde kalmıştır. Söz konusu dönemde Bahreyn ve Umman, toplam KRG puanına önemli oranda katkı sağlayan bu bileşen bağlamında azalma yaşamışlardır. Alt bileşenler bağlamında bakıldığında Bahreyn'deki azal1şın temel nedeni makroekonomik istikrar puanında yaşadığı önemli düşüş olduğu görülmektedir. Umman'ın ise her ne kadar bazı alt göstergeler bağlamında artış göstermişse de Bahreyn gibi makroekonomik istikrar alt bileşeninde yaşanan azalış nedeniyle toplam puanında azalma yaşanmıştır. ${ }^{48}$

Yükseköğretim ve eğitim, ürün piyasasının etkinliği, işgücü piyasasının etkinliği, finans piyasasının gelişmişliği, teknolojik hazırlık ve piyasa büyüklüğü gibi altı alt bileşenin puanlanmasından oluşan etkinlik arttırıcılar alanı, çalışma kapsamında yer alan ülkeler için küresel rekabetçilik puanının hesaplanmasında en yüksek ağırlığa sahip bileşendir. İncelemeye konu dönemde bölge ülkelerinden sadece Kuveyt, siyasal karar mekanizmalarındaki politik bölünmüşlüklerin/karşıtlıkların etkisiyle ekonomik rekabet gücünü arttıracak unsurlara eğilememiş ve bu nedenle etkinlik arttırıcılar skorunda bir azalma gerçekleşmiş olup, diğer ülkelerin yükseliş trendi içerisinde bulundukları görülmektedir. Bu dönemde en büyük gelişimi Birleşik Arap Emirlikleri ile Katar göstermiş bulunmaktadır. Her iki ülkenin, bu süreçte bütün alt bileşenler bağlamında yakaladıkları yükseliş trendi sayesinde elde ettikleri küresel rekabet gücü artışı esasen teknoloji içeriği ve katma değeri yüksek mal ve hizmet üretimine yoğunlaşmanın, yani teknolojik hazırlık alt bileşenindeki gelişimin etkisiyle gerçekleşmiş bulunmaktadır. Keza Suudi Arabistan'da, tıpkı BAE ve Katar'da olduğu gibi, teknolojik hazırlık alt bileşeninde yakaladığı ivmenin de etkisiyle puanını yükseltmeyi başarmıştır. ${ }^{49}$

İşletme gelişmişliği ile inovasyon alt bileşenlerinin meydana getirdiği inovasyon ve gelişmişlik faktörleri bileşeni, küresel rekabet edilebilirliğinin

48 World Economic Forum ve European Bank for Reconstruction. The Arab World Competitiveness Report 2013, (2013): 12, 14; World Bank, Doing Business 2012, 73; World Bank, Doing Business 2015, 21, 48, 65, 76.

49 World Economic Forum ve European Bank for Reconstruction, The Arab World Competitiveness Report 2013, 12-17. 
sağlanması ile bu durumun sürdürülebilirliğini teminen en önemli faktör olarak ön plana çıkmaktadır. Zira inovasyon gerek şirketlerin gerekse ülkelerin dış piyasalarda rekabet edebilirliğinin en önemli koşullarından biri haline gelmiştir. Katma değeri yüksek ürün ve hizmetlerin meydana getirilmesi ve uluslararası telif yasaları gibi nedenlerle oldukça yüksek fiyatlar ile ihracının ön plana çıktığı küresel ekonomik sistemde, rekabet gücü performanslarını yükseltmek ve böylelikle kalkınma hamlelerini sürdürülebilir kılmak isteyen ülkelerin bu faktörlere yatırım yapması bir zaruret halini almıştır. Körfez ülkelerinde inovasyon ve gelişmişlik faktörlerinin gelişimi incelenecek olursa, Katar ve BAE'nin diğer bileşenlerde olduğu gibi inovasyon ve gelişmişlik faktörleri bileşeninde de yükselme trendinde olduğu; anılan ülkelerin özellikle sağlık, havacılık-uzay, finansal hizmetler, yenilenebilir enerji, nano-teknoloji, bio-teknoloji ve benzeri birçok ileri teknoloji gerektiren alanda AR-GE harcamalarını arttırmak suretiyle bilim ve yüksek teknoloji ihtiva eden sanayi politikalarına özel bir önem vererek Katar'1n 4,1 olan endeks puanını 5,0'a, BAE ise yine 4,1 olan endeks puanın 4,9'a yükselttiği anlaşılmaktadır. Bu gösterge bağlamında azalış gösteren ya da beklenen/arzu edilen düzeyde gelişim gösteremeyen diğer Körfez Arap ülkelerinin inovasyon alanına beklenen düzeyde yatırım yapmadıkları, alt bileşenlerdeki trend izlendiğinde ortaya çıkmaktadır. ${ }^{50}$

Bütün bu göstergeler, erken dönem rantiyer devlet ve uzmanlaşmış rantiyer devlet tecrübelerinden dersler çıkaran Körfez Arap ülkelerinde, sorumlu fakat demokratik olmayan yönetimlerin varlığını sürdürdüğü, bazı korumacılık uygulamalarına devam edilmekle birlikte küreselleşmenin olgusuna eklemlenmeye gayret eden, uzun vadeli bir ekonomi ve kalkınma vizyonu bulunan, enerji-merkezli ekonomik yapısını enerji-güdümlü bir yapıya evirmeye çalışan ve fakat girişimci devlet kapitalizmi uygulamasının da devam ettirildiği, etkin ve yenilikçi bir dış politika anlayışını benimseyen bir devlet yapısının ön plana çıkması suretiyle, geç dönem rantiyer devlet aşamasına geçildiği hususunu desteklemektedir. ${ }^{51}$

50 World Economic Forum ve European Bank for Reconstruction, The Arab World Competitiveness Report 2013, 12, 14.

51 Gray, "A Theory," 23-36. 


\section{Körfez Ülkelerinde Rekabet Gücü Performansı Unsurlarının Analizi}

Bu noktada, Tablo 5'te yer alan verilerden de faydalanmak suretiyle farkl1 KRG skoru ve bileşen puanlarına sahip Körfez Arap ülkelerinin, 20162017 dönemi küresel rekabet gücü performansları, alt unsurlar da göz önünde bulundurulmak kaydıyla dinamik ve karşılaş̧ırmalı olarak incelenmektedir. Böylelikle her ülkenin ekonomik kalkınma ve rekabet gücü potansiyelinin açık bir şekilde ortaya konulması, sonuç odaklı ve somut hedeflerle desteklenmiş bir politika seti belirlenmesi ile hedeflere ulaşmak için yapılması zorunlu eylemlerin ve bunun sorumlularının ortaya konulması amaçlanmaktadır.

Daha önce de ifade edildiği üzere KRG endeksinin üç temel bileşeni bulunmakta olup, bu üç bileşen de on iki alt bileşenden oluşmaktadır. Temel gereksinimlerin alt bileşenleri olan kurumlar yirmi bir, altyapı dokuz, makroekonomik istikrar beş, sağllk ve ilköğrenim on alt unsurdan; etkinlik arttırıcıların alt bileşenleri olan, yükseköğrenim ve eğitim sekiz, mal piyasası verimliliği on alt1, işgücü piyasası verimliliği on, finansal piyasaların gelişmişliği sekiz, teknolojik hazlrlı yedi, piyasa büyüklüğü dört alt unsurdan; inovasyon ve gelişmişlik faktörlerinin alt bileşenleri olan işletme gelişmişliği dokuz ve inovasyon ise yedi alt unsurdan meydana gelmektedir. Alt bileşen endeks puanlarının oluşturulması kullanılan bu alt unsurların da analiz edilmesi ile ülkelerin küresel rekabet gücü performanslarına dair güçlü ve zayıf yönlerinin esasen hangi nedenlerden kaynaklandığının ve çözümün hangi noktalarda yoğunlaşması gerektiğinin tespiti imkânına sahip olunabilecektir. Tablo 5 'te yer alan veriler öncelikle incelendiğinde göze çarpan temel husus, BAE ve Katar'ın diğer bölge ülkelerine nazaran başarılı ve üstün durumudur. Bu bileşen ve alt bileşenlerin sadece birisi -piyasa büyüklüğü- hariç olmak üzere diğer bileşen ve alt bileşenlerde, diğer ülkelere nazaran ve hatta dünyanın gelişmiş pek çok ekonomisi ile de mukayese edilebilecek düzeyde iyi bir performans sergilemiş durumdadırlar. Bölge ülkeleri içerisinde en düşük performansa sahip ülkenin ise Umman olduğu görülmektedir.

2016-2017 y1lı KRG endeks puanı 5,3 ile 138 ülke içerisinde 16'nc1 s1rada bulunan ve inovasyon odaklı ekonomi olarak tasnif edilen BAE'nin en başarılı olduğu alanlar; ürün piyasası etkinliği (3/138), altyap1 (4/138) ve kurumlar (7/138) olarak ön plana çıkmakta; diğer yandan, ülkenin en düşük performans sergilediği alanlar ise sağlık ve ilköğretim (40/138) ile 
makroekonomik istikrar (38/138) olarak sıralanmaktadır. Birleşik Arap Emirlikleri, yatırımların vergilendirilmesindeki etkinliği, ticaretin önündeki engellerin düşüklüğü ile gümrük prosedürlerinin basitleştirilmesi gibi alt unsurlardaki başarısı ile ürün piyasası etkinliği alt bileşeninde oldukça yüksek performans göstermektedir. Her ne kadar enerji fiyatlarında yaşanan düşüşler nedeniyle enflasyon ve kamu borcu artışı gibi önemli makroekonomik istikrar sorunları yaşamaktaysa da güçlü kurumsal kapasitesi, gelişen fiziki altyapısı, yönetimin enerji-odaklı ekonomik yapının dönüşümüne dair iradesi ve AR-GE yatırımlarının da etkisiyle bu sorunları bertaraf ederek küresel rekabet gücünü tahkim ettiği anlaşılmaktadır. Öte yandan, BAE'de işgücü piyasanın etkin ve ücretlerin esnek olması, eğitim sistemi ve okul kalitesinin iyi düzeyde bulunması, yetenekli insanları çekme ve istihdam edebilme potansiyelinin varlığ 1 , biraz evvel de ifade edilen küresel rekabet gücü artışını desteklemektedir. Buna göre, okullaşma oranının arttırılması ve kadın istihdamının güçlendirilmesi gibi hususlarda yapılacak atılımlar ile bilimsel araştırma kurumlarının kalitesini arttırmaya yönelik faaliyetlerin, ülkenin genel inovasyon kapasitesini yükselteceği ve böylece küresel rekabet gücünü daha yüksek seviyelere çıkaracağı söylenebilmektedir.

2016-2017 y1lında 5,2 olan KRG Endeksi puanı ile 138 ülke içerisinde 18 'inci sırada yer alan ve inovasyon odakl1 ekonomi olan Katar'in en başarılı olduğu alanlar, makroekonomik istikrar (2/138) ile ürün piyasası etkinliği (7/138); en başarısız olduğu alan ise piyasa büyüklüğü (50/138) olarak gözükmektedir. Makroekonomik istikrarın güçlü olduğu, finansal piyasaların gelişmiş olduğu ve banka kredilerine erişim prosedürlerinin basitleştirildiği, doğrudan yabancı yatırımları ile ileri teknoloji transferinin sağlandığ 1 Katar, ücretlerin ve işten çıkarma maliyetinin yüksek olduğu, yetenekli personel istihdamı ve sürdürülebilirliğine sahip olan, genel olarak eğitim kalitelisinin yüksek ancak okullaşma oranının düşük olduğu bir görünüm arz etmekte; kadın istihdamı ise düşük düzeylerde kalmaktadır. Bu bağlamda, işgücü piyasasının daha etkin kılınması, yükseköğretim ve eğitim ile altyapının daha güçlü bir hale getirilmesi sayesinde genel inovasyon kapasitesinin yükseltilmesine matuf politikaların uygulanması durumunda, ülkenin küresel rekabet edebilirlik potansiyelinin daha yüksek seviyelere çıkacağ 1 ve sürdürülebilir olacağı değerlendirilmektedir. 


\section{Tablo 5: Körfez Ülkelerinde Küresel Rekabet Gücünün Unsurları} (2016-2017)

\begin{tabular}{|c|c|c|c|c|c|c|}
\hline & Bahreyn & BAE & Katar & Kuveyt & $\begin{array}{c}\text { Suudi } \\
\text { Arabistan }\end{array}$ & Umman \\
\hline Temel Gereksinimler & 5,0 & 5,9 & 6,1 & 5,1 & 5,2 & $\mathbf{5 , 0}$ \\
\hline Kurumlar & 5,0 & 5,8 & 5,7 & 4,1 & 5,1 & 5,0 \\
\hline Altyapr & 5,0 & 6,3 & 5,6 & 4,4 & 5,1 & 4,8 \\
\hline Makroekonomik İstikrar & 3,9 & 5,3 & 6,7 & 6,3 & 4,7 & 4,5 \\
\hline Să̆llk ve İlkögrretim & 6,2 & 6,2 & 6,3 & 5,6 & 6,0 & 5,7 \\
\hline Etkinlik Arttırıcılar & 4,5 & 5,2 & 5,0 & 4,1 & 4,7 & 4,2 \\
\hline Yükseköğrenim ve Ĕgitim & 4,9 & 5,1 & 5,1 & 4,0 & 4,8 & 4,1 \\
\hline Mal Piyasası Verimliliği & 5,0 & 5,6 & 5,4 & 4,2 & 4,6 & 4,5 \\
\hline$\dot{I}_{\text {şgücü Piyasası Verimliliği }}$ & 4,6 & 5,2 & 5,0 & 3,7 & 4,3 & 4,1 \\
\hline Finansal Piyasaların Gelişmesi & 4,3 & 4,7 & 4,8 & 4,0 & 4,2 & 4,2 \\
\hline Teknolojik Hazırlık & 5,2 & 5,8 & 5,3 & 4,3 & 5,0 & 4,4 \\
\hline Piyasa Büyüklüğü & 3,2 & 4,9 & 4,3 & 4,3 & 5,4 & 3,8 \\
\hline İnovasyon ve Gelişmişlik Faktörleri & 4,0 & 4,9 & $\mathbf{5 , 0}$ & 3,5 & 4,1 & 3,6 \\
\hline İsletme Gelişmişliği & 4,4 & 5,2 & 5,2 & 4,0 & 4,5 & 3,9 \\
\hline Ínovasyon & 3,6 & 4,6 & 4,9 & 3,0 & 3,7 & 3,3 \\
\hline
\end{tabular}

Kaynak : World Economic Forum, The Global Competitiveness Report 2016-2017, ed., Klaus Schwab (2016).

2016-2017 y1lında 4,8 olan KRG Endeksi puanı ile 138 ülke içerisinde 29 'uncu sirada yer alan ve etkinlik odaklı ekonomiden inovasyon odak11 ekonomiye geçiş aşamasında (2-3 Geçiş Ekonomisi) bulunan Suudi Arabistan'ın en başarılı olduğu alanlar piyasa büyüklüğü (14/138) ve kurumlar (24/138) iken; en başarısız olduğu alanlar ise makroekonomik istikrar (68/138) ile işgücü piyasası verimliliği (65/138) olarak ön plana çımaktadır. Ekonomik büyüklüğü, yüksek nüfusu, coğrafi konumu ve askeri kapasitesi ile bölgenin kilit ülkesi olan Suudi Arabistan'in görece makroekonomik istikrarı, enerji fiyatlarındaki dalgalanmaların da etkisiyle bozulmaya yüz tutmuştur. Aynı zamanda işgücü ve ürün piyasasında etkinlik sorunları da bulunan Suudi Arabistan, yüksek petrol gelirleriyle bağlantıl1 olarak küresel ölçekte önemli bir potansiyel taşımakla birlikte, finansal sisteminin gelişmişliği bakımından istikrarsız bir görünümüne sahiptir. Yine Suudi Arabistan'da işe başlama prosedürlerinin yüksek olduğu, yabanc1 yatırımcıların mülkiyet edinme haklarının kısıtlanması bağlamında doğrudan yabancı sermaye yatırımlarının önünde engellerin bulunduğu da bilinmektedir. İşten çıkarma maliyetlerinin yüksek olduğu ve kadın işgücünün son derece sınırlı olduğu ülkede işletme gelişmişliği ve inovasyon faktörü azalma trendi göstermektedir. Kurumsal yapının güçlendirilmesi, altyapı 
kalitesinin arttırılması gibi temel gereksinimlerin karşılanması yanında etkinlik artıcı faktörlerde gelişme sağlanması ile ülkenin piyasa büyüklüğü avantajını da kullanarak inovasyon odaklı ekonomiye geçilebileceği ve böylelikle Suudi Arabistan'ın rekabet gücü performansının yükseltilebileceği değerlendirilmektedir.

2016-2017 y1lında 4,5 olan KRG Endeks puanı ile 138 ülke içerisinde 38'inci sırada bulunan Kuveyt'in en başarılı olduğu alan makroekonomik istikrar (6/138); en başarısız olduğu alanlar ise işgücü piyasası verimliliği $(115 / 138)$ ile inovasyon (110/138) bileşenleridir. Faktör-odakl1 ekonomiden etkinlik-odaklı ekonomiye geçiş (1-2 Geçiş Ekonomisi) aşamasındaki ülkeler kategorisinde tasnif edilen Kuveyt, küresel rekabet gücünü arttırma noktasında özel ve kamu kurum/kuruluşlarının işleyiş̧inin etkinleştirilmesi, fiziki altyapının geliştirilmesi, istikrarlı bir makroekonomik çerçevenin temini ile en azından temel eğitim almış sağl1klı bir işgücünün yetiştirilmesi sayesinde dünya piyasalarında rekabet edebilecek katma değeri yüksek üretim düzeyine erişebilecektir. İşüucü piyasasında, finansal sistemde ve ürün piyasalarında önemli etkinlik sorunları bulunan Kuveyt'e dair göstergeler tetkik edildiğinde, kurumsal yapının güçlendirilmesi ve altyapı kalitesinin arttırılması gibi temel gereksinimlerin karşılanması yanında, etkinlik artıcı faktörlerde ve inovasyon alanında sağlanacak gelişmelere odaklanmasının gerekliliği ortaya çıkmaktadır.

2016-2017 yılında 4,5 olan KRG Endeksi puanı ile 138 ülke içerisinde 48'inci sırada yer alan ve inovasyon odaklı ekonomi konumunda bulunan Bahreyn'in en başarılı olduğu alanlar ürün piyasası etkinliği (22/138) ile kurumlar (25/138) iken; en başarısız olduğu alanlar ise makroekonomik istikrar (113/138) ile piyasa büyüklüğü (92/138) bileşenidir. Körfez ülkeleri içerisinde en düşük nüfusa ve en küçük yüzölçümüne sahip ülkesi olan Bahreyn, Katar ile birlikte önemli bankacılık, finans ve sermaye piyasaları merkezlerine sahip bulunmaktadır. Modern bir iletişim ve ulaşım altyapısı bulunan ve çok sayıda çokuluslu şirkete ev sahipliği yapan Bahreyn'de, enerji fiyatlarındaki dalgalanmalar ile birlikte bütçe dengesinde ciddi derecede bozulmalar yaşanmış, bu durum ülkede makroekonomik istikrarın sarsılmasına ve böylece küresel rekabet gücü performansına olumsuz etkide bulunmuştur. Kurumsal yapısı ve fiziki altyapısı gelişmiş bir ada ülkesi olan Bahreyn'in piyasa büyüklüğü sıkıntısı çoğu kez ölçek ekonomilerinden faydalanmasının önündeki bir engel olmuş; diğer yandan birçok Kör- 
fez ülkesi gibi okullaşma oranları düşük ve fakat eğitimin kalite düzeyi genel olarak iyi seviyede olmuştur. Bahreyn'in, başta etkinlik arttırıcılar ve kısmen de temel gereksinimler faktörlerindeki etkinlik sorunlarını giderecek düzenleme hamlelerini gerçekleştirmesi, AR-GE yatırımları, bilimsel araştırma kalitelerini yükseltmeye yönelik çalışmalara ağırlık vermesi sayesinde genel inovasyon kapasitesinin güçlendirilmesinin, ülkenin küresel rekabet gücüne olumlu katkı yapacağı değerlendirilmektedir.

2016-2017 y1lında 4,3 olan KRG Endeksi puanı ile 138 ülke içerisinde 66'ncı sırada bulunan Umman'in en başarılı olduğu alanlar kurumlar (28/138) ve altyap1 (38/138) iken; en başarısız olduğu alan ise yüksek öğrenim ve eğitim (85/138) olarak ön plana çıkmaktadır. Etkinlik-odak11 ekonomiden inovasyon odaklı ekonomiye geçiş aşamasında (2-3 Geçiş Ekonomisi) bulunan Umman, eğitim-öğretim ve sağlık alanında yapılacak yatırımlarla beşeri sermayenin gelişimine katkıda bulunması yanında işgücü ve ürün piyasası ile finansal sisteme yönelik etkin düzenlemeler geliştirmesi dolayısıyla temel gereksinimler ve etkinlik arttırıcılara odaklanarak inovasyon odaklı ekonomiler seviyesine yükselebileceği değerlendirilmektedir. Bununla birlikte, ülkenin inovasyon kapasitesini arttırmaya yönelik, biyoteknoloji, nanoteknoloji gibi bilgi-odaklı ekonomilere yapacağı AR-GE yatırımlarının makroekonomik istikrarın temini ile kalkınma hamlelerinin ve rekabetçilik performansının yükseltilmesi noktasında önemli olduğu da ortadadır.

\section{Sonuç}

21 'inci yüzyılı şekillendiren, bu çerçevede bütün değerlerin sorgulanmasina ve form değiştirmesine yol açan küreselleşme olgusu, ekonomi içerisinde devlete biçilen rol ve verilen görev noktasında da büyük bir değişimin yaşanmasına neden olmuştur. Esasen, iktisadın bir bilim olarak ortaya çıktığı günden bu yana söz konusu hususa dair görüş birliğine varılabilmiş değildir. Şöyle ki, önceleri devlete ekonomi içerisinde kısıtlı bir alan tanıyan klasik iktisadi anlayış, çoğu kez dönemsel şartların ve gelişmelerin de etkisiyle yerini devletin ekonomide son derece önemli bir aktör halini almasını ögütleyen teorik bir izahata bırakmıştır. Ancak bu süreç, özellikle iki büyük Dünya Savaşı ve akabinde yaşanan Soğuk Savaş sonunda, bu ortamdan galip çıkmak suretiyle küresel anlamda egemenliğini ve etkisini 
önemli ölçüde arttıran ABD'nin de etkisiyle, devletin ekonomide sınırlı bir yeri olan minimalist devletlerin var olduğu bir iktisadi anlayışa evrilmiştir. ABD merkezli bu kapsamlı ve köktenci dönüşüm/değişim süreci, küreselleşme olgusunun da dinamik itici etkisiyle, neo-liberal politikaların öncülendiği, iş birliği ve rekabetin ön plana çıktığı bir ortamın oluşmasına sebebiyet vererek, dünya genelinde her ülkeyi bir şekilde etkilemiştir. Birçok gelişmekte olan ülke bu değişim hamlesi için hevesli bir tutum sergilemek suretiyle şok politikalar gerçekleştirmişler ise de diğer bazı ülkelerin anılan dönüşüm trendine intibakı daha uzun bir döneme yayılmıştır.

Jeostratejik konumları, sahip oldukları yüksek doğal kaynak rezervleri ve bölgesel ticaretin merkezinde olmaları gibi nedenlerle küresel hegemonik güçlerin her daim ilgisini çeken Körfez Arap Ülkeleri İşbirliği Konseyi üyesi Bahreyn, Birleşik Arap Emirlikleri, Katar, Kuveyt, Suudi Arabistan ve Umman'da, 2'nci Dünya Savaşı sonrasında bağımsızlıklarını kazanmalarını müteakip, 1950-1980 döneminde herhangi bir kalkınma perspektifi bulunmayan ve patrimonyal ilişkilere dayanan siyasal yapının hâkim olduğu, gelirlerinin neredeyse tamamını enerji ihracatından elde eden, bu gelirlerin devlet-toplum arasında paylaştırılmasına dayalı zımni bir anlaşmaya binaen dağıtıcı özellik gösteren, klasik rantiyer devlet görünümüne bürünmüşlerdir. Her geçen gün anılan ülkelerin siyasal, toplumsal ve ekonomik sistemlerine daha da nüfuz eden rantiyer ilişkiler bütünü, 1980'li yıllarda enerji fiyatlarında görülen azalma trendi ile birlikte devlet-toplum ilişkilerinin sorgulanmasına neden olmuştur. Her ne kadar birikmiş fonların taraflar arasında paylaşımı ve yerleşik siyasal elitler ile güçlü güvenlik bürokrasisinin toplum üzerindeki sindirici etkisiyle sosyal tansiyon kontrol altına alınmış ise de bu yaşananlardan önemli dersler çıkaran ve Hollanda hastalığ , kaynakların laneti, dışlama etkisi gibi olguları aşmaya matuf gayret içerisinde bulunan Körfez Arap ülkeleri, ekonomik, politik ve sosyal kurumlarına ilişkin dönüşümün gerekliliği konusunda ikna olmuşlardır.

Özellikle 1990'lı yıllarda dünya sathında yaşanan borç krizleri ile birlikte, uluslararas1 ekonomik kuruluşların sürükleyiciliğinde devletin ekonomi içerisindeki rolünün azaltılması, özelleştirme, deregülasyon uygulamalar1 doğrultusunda ekonomik reform gündemleri oluşturulmuş; ayrıca sosyal ve siyasal kurumların restorasyonuna dair tavsiyeler de bu ajandalar dâhilinde önemli bir yer tutmuştur. Bu dönüşüm sürecinde Körfez Arap ülkeleri de özellikle dış ticarete yönelik kısıtlamaları azaltıp işlem mali- 
yetlerini düşürecek birtakım düzenlemelere gitmişler; ancak gerek özelleştirme ve deregülasyon gerekse siyasal katılımcılığın arttırılması, hukukun üstünlügünün yerleştirilmesi ve temel hak ve hürriyetlerin güvencesi gibi yönetişim unsurlarına gereken önemi vermemişleridir. Keza, küresel ekonomik ilişkilerin oldukça geliştiği ve bu sisteme entegrasyonun kaçınılmaz olduğu 2000'li yıllar ile birlikte Körfez Arap ülkelerinde de -siyasal ve sosyal alanlarda olmasa da- ekonomik temelli stratejik birtakım hamleler gerçekleştirilmeye başlanmıştır.

Serbest piyasa kapitalizmi olarak da adlandırılan bu yenidünya sisteminde, Körfez Arap ülkelerinin, verimlilik artışının temin edilmesi suretiyle yüksek katma değer üretebilme kapasitesinin arttırılması ve böylelikle ekonomik rekabet gücünün yükseltilmesine yönelik çabalarının detaylı bir analize tabi tutulduğu bu çalışma neticesinde, öncelikle söz konusu reformların, bu ülkelerde iş/çalışma ve yatırım/girişimcilik hayatında özgür/kapsayıcı bir ortamın oluşmasını ve bazı ülkelerin bölgenin finans ve bankacılık merkezi konumuna yükselmesini sağladığı görülmüştür. Birleşik Arap Emirlikleri ve Katar, özellikle altyapı ve teknolojik yatırımlar alanındaki hamleleri ile yatırım ortamının iyileştirilmesine dair kapsayıcı düzenlemeler gerçekleştirmeleri sayesinde küresel rekabet gücü performanslarını diğer bölge ülkelerine nazaran daha iyi bir seviyeye çıkarmışlar ve böylece dünya s1ralamasında iyi bir pozisyona erişmişlerdir. Diğer Körfez Arap ülkelerinin ise bazen geleneksel toplumsal yapıları, bazen komşularındaki siyasal çatışma ortamının yansıması, bazen de yüzölçümü ve nüfus büyüklüğünün getirdiği handikaplar neticesinde ortaya çıkan ekonomik motivasyon farkl11ıkları/sapmaları gibi nedenlerle rekabet gücü artışlarını gelişmiş ülkeler seviyesine çıkaramadıkları müşahede edilmiştir. Her ne kadar ülkeden ülkeye farkl1l1klar içerse de, genel olarak Körfez Arap ülkelerinin işgücü, finans, mal ve hizmet piyasalarında etkinlik sorunları barındırdıkları, fikri ve sınaî mülkiyet haklarının güvencesine dair algının kuvvetli olmadığı, fiziki altyapı eksikliklerinin bulunduğu, eğitim ve öğretim planlama ve kalitesinin sistematik problemler barındırdığı, en önemlisi de anılan ülkelerde inovasyon kapasitesinin yeterli bulunmaması sebebiyle bilgi ekonomileri ve AR-GE yatırımlarının düşük düzeyde kaldığı görülmüştür.

Bununla birlikte, küreselleşme sürecinin sürükleyici etkisi altında, rantiyer devlet teorisinin devlet-toplum arasındaki zımni anlaşma bağlamında öngördüğg̈ temel/birincil düzey ilişki biçiminden kısmen kurtulan Körfez 
ülkeleri, sınırlı da olsa artan ekonomik rekabet gücünün sağladığı konforlu ortam nedeniyle siyasal yönetim biçimleri ve hukuk sistemlerine dair reform gündemlerini sürekli olarak erteleme yolunu tercih etmişlerdir, ta ki Arap İsyanları sürecine kadar... Genelde Ortadoğu, özelde ise Körfez ülkelerinin önündeki en büyük sorunlar yumağı olarak duran siyasal kat1lımc1lık ve hukuk güvenliği problemlerinin hem toplumsal tansiyonun düşürülmesi hem de bahse konu sınırlı ekonomik rekabet gücü artışının daha da sağlam temellere oturtulabilmesi yolunda, ötelenemeyecek bir gündem olduğu, Arap İsyanları süreciyle birlikte aşikâr hale gelmiştir.

Son dönemde konjonktürel bazı kırılmalar görülse de, Körfez ülkelerinin güçlü yapısal ve kültürel bağları ile ekonomik menfaatleri temelinde, 1981 yılında kurdukları Körfez Arap Ülkeleri İşbirliği Konseyi’nin, ekonomik bütünleşme ile sosyal konsolidasyonu gerçekleştirme hedefi çerçevesinde, ülkelerde yönetişim boşluğunu gidermek, kurumsal yapılarını yakınlaştırmak, çeşitli alanlarda ortak bilimsel ve teknik projeler oluşturmak suretiyle küresel rekabet gücü performanslarının sürdürülebilir bir zemine kavuşturulması noktasında önemli bir rol oynayabileceği düşünülmektedir. Buna göre, Körfez ülkelerinin, Konsey'in dinamik etkisi ve birbirlerinin tecrübelerinden faydalanmak suretiyle fiziki ve beşeri altyapılarını kuvvetlendirmek, ürün, işgücü ve finans piyasalarında verimliliği arttırmak ile inovatif yatırımlara odaklanmak suretiyle, mevcut rekabetçi özelliklerini daha da geliştirmeleri önem taşımaktadır. Bu doğrultuda, geç dönem rantiyer devlet formlarından kaynaklanan potansiyel toplumsal kırılganlıkların ise siyasal katılımcılığın inşa edilmesi, hukuk güvenliğini temin edecek bir adli mekanizmanın tasarlanması, şeffaf ve hesap verilebilir yönetim anlayışının benimsenmesi, uygulanması ve etkin/kararlı bir şekilde izlenmesi sayesinde bertaraf edilebileceği değerlendirilmektedir.

\section{Kaynakça}

Acemoğlu, Daron ve James A. Robinson. Ulusların Düşüşü - Güç, Zenginlik ve Yoksulluğun Kökenleri. çev. Faruk Rasim Velioğlu. İstanbul: Doğan Kitap, 2013.

Adıgüzel, Muhittin. "Küresel Rekabet Gücünün Ölçülmesi ve Türkiye Bağlamında Bir Değerlendirme.” Akademik Bakış no. 37 (2013): 1-21.

Anderson, Lisa. "The State in the Middle East and North Africa." Comperative Politics 20 no. 1 (1987): 1-18. 
Arı, Tayyar ve Ferhat Pirinççi. “Soğuk Savaş Sonrasında ABD'nin Balkan Politikası.” Alternatif Politika 3 no. 1 (2011): 1-30.

Aysan, Ahmet Faruk. "Yönetişim ve Kurumlar Kavramlarının İktisat Literatüründeki Yükselişi Üzerine Bir Değerlendirme." Uluslararası Ekonomi ve Dış Ticaret Politikaları Dergisi 1 no. 2 (2007): 27-52.

Balcıoğlu, Hasret ve Diğerleri. Kuzey Kıbrıs 2015-2016 Rekabet Edebilirlik Raporu. Kıbrıs Türk Ticaret Odası Yayınları (2016).

Beblawi, Hazem. "The Rentier State in the Arab World." The Arab State. ed. Giacomo Luciani. London: Routledge, (1990): 85-98.

BP. Statistical Review of World Energy - 2016 Update. (2017).

Bromley, Simon. "Ortadoğu'da Devletler Sistemi - Kökeni, Gelişimi ve Geleceği." Ortadoğu Tarihi - Dini, Siyasi, Kültürel ve Ekonomik Perspektiften. ed. Youssef M. Choueiri. çev. Fethi Aytuna. İstanbul: İnk1lâp Yayınlar1 (2011): 598-633.

Chhibber, Ajay. "The State in a Changing World." Finance \& Development (1997): 17-20.

Çevik, Savaş ve Erol Turan. "Devletin Kurumsal Dönüşümü: Orta Asya Cumhuriyetleri Perspektifinden.” Bilig no. 41 (2007): 204-24.

Çivi, Emin. "Rekabet Gücü: Literatür Araştırması." Yönetim ve Ekonomi 8 no. 2 (2001): 22-38.

Economist Intelligence Unit. Democracy Index 2014- Democracy and Its Discontents (2015).

Freedom House. Freedom in the World 2013 - Methodology. 21.10.2013.

Gökmenoğlu, Seyit ve Diğerleri. "Ulusal Rekabet Gücünü Belirleyen Faktörler Üzerine Değerlendirmeler.” Rekabet Dergisi 13 no. 4 (2012): 3-43.

Gray, Matthew. 'A Theory of 'Late Rentierism' in the Arab States of the Gulf.” CIRS Occasional Paper no. 7 (2011).

Gurbanov, Sarvar. Hollanda Hastalığı: Teori ve Ülke Örnekleri. İstanbul: Akis Kitap (2012).

Gürak, Hasan. Ekonomik Büyüme ve Küresel Ekonomi. Bursa, Ekin Kitabevi (2006). 
Gwartney, James D. ve Diğerleri. Economic Freedom of the World: 2010 Annual Report (2010).

Hanieh, Adam. İsyanın Kökenleri- Kapitalizmin Ortadoğu'daki Sorunları. çev. Ali Toprak. Ankara: Notabene Yayınları (2015).

Hanke, Steve H. ve Stephen J. K. Walters. "Economic Freedom, Prosperity and Equality: A Survey." Cato Journal 17 no. 2 (1997): 117-46.

Kaufmann, Daniel, Aaart Kraay ve Massimo Mastruzzi. "The Worldwide Governance Indicators- Methodology and Analytical Issues." The World Bank Policy Research Working Paper no. 5430 (2010).

Levitsky, Steven ve Lucan A. Way. "The Rise of Competitive Authoritarianism." Journal of Democracy 13 no. 2 (2002): 51-65.

Luciani, Giacomo. "Allocation vs. Production States: A Theoretical Framework." The Arab State. ed. Giacomo Luciani. London: Routledge (1990): 65-84.

Mahdavy, Hossein. "The Patterns and Problems of Economic Development in Rentier States: The Case of Iran." Studies in the Economic History of the Middle East-From the Rise of Islam to the Present Day. ed. M. A. Cook. Oxford: Oxford University Press (1970): 428-67.

Miller, Terry ve Anthony B. Kim. "Defining Economic Freedom." Index of Economic Freedom 2014, The Heritage Foundation and The Wall Street Journal Report. ed. Terry Miller ve Diğerleri (2014): 79-86.

Murden, Simon. "Politik Ekonomi - Modernleşmeden Küreselleşmeye." Ortadoğu Tarihi Dini, Siyasi, Kültürel ve Ekonomik Perspektiften. ed. Youssef M. Choueiri. çev. Fethi Aytuna. İstanbul: İnkılâp Yayınları (2011): 443-63.

North, Douglass C. Kurumlar, Kurumsal Değişim ve Ekonomik Performans. çev. Gül Çağalı Güven. İstanbul: Sabancı Üniversitesi Yayınları (2002).

Ovalı, Serap. "Küresel Rekabet Gücü Açısından Türkiye'nin Konumu Üzerine Bir Değerlendirme." International Journal of Economic and Administrative Studies 7 no. 13 (2014): 17-36.

Özkoç, Özge. "Türkiye'nin Kuzey Afrika'ya Yönelik Politikası: Bir Modelin Çöküşü.” Ankara Üniversitesi Siyasal Bilgiler Fakültesi Dergisi 72 no. 1 (2017): 77-97. 
Pirinççi, Ferhat. “Soğuk Savaş Sonrasında ABD’nin Orta Asya Politikası: Beklentiler ve Gerçeklikler.” Ankara Üniversitesi Siyasal Bilgiler Fakültesi Dergisi 63 no. 1 (2008): 207-35.

Property Rights Alliance. International Property Rights Index 2013. (2013).

Ross, Michael. "Does Oil Hinder Democracy?." World Politics 53 no. 3 (2011): 325-61.

Saghir, Jamal. "Infrastructure Privatization in the MENA Region." State State-Owned Enterprises in the Middle East and North Africa-Privatization, Performance and Reform. London: Routledge (2001): 89-127.

Sala-i-Martin, Xavier ve Diğerleri. "Reaching Beyond the New Normal: Findings from the Global Competitiveness Index 2015-2016." The Global Competitiveness Report 2015-2016. ed. Klaus Schwab. (2015).

Stevens, Paul. "Petrol ve Kalkınma." Ortadoğu Tarihi Dini, Siyasi, Kültürel ve Ekonomik Perspektiften. ed. Youssef M. Choueiri. çev. Fethi Aytuna. İstanbul: İnkılâp Yayınları (2011): 485-504.

Sune, Engin ve Ali Murat Özdemir. "Rantçı Devlet Yazını Üzerine Deneme." Uluslararası İlişkiler 9 no. 35 (2012): 3-31.

Şimşek, Orhan. Küreselleşme ve Yeni Devlet Kapitalizminin Yükselişi. Ankara: Türk Metal Sendikası Araştırma ve Eğitim Merkezi Yayınları (2017).

Taşıran, Ali Cevat ve Burçak Özoğlu. Kuzey Kıbrıs 2016-2017 Rekabet Edebilirlik Raporu. Kıbrıs Türk Ticaret Odası Yayınları (2017).

The Political Risk Services Group."International Country Risk Guide Methodology," 16.06.2014. http://www.prsgroup.com/wp-content/uploads/2012/11/icrgmethodology.pdf.

"The Rise of State Capitalism." The Economist. 26.06.2012. https://www. economist.com/nod e/21543160.

Transparency International. Corruption Perceptions Index 2013 - Brochure (2013).

Uğur, Mehmet. "Kurumsal Kalite ve Ekonomik Performans - İktisadın (Yeniden) Siyasallaşması mı?.” İktisat ve Toplum no. 9 (2011): 36-41. 
Ünay, Sadık. Kalkınmacı Modernlik - Küresel Ekonomi Politik ve Türkiye. İstanbul: Küre Yayınları (2013).

Wang, Tai-Yue ve Diğerleri. "A Research Framework for Evaluating the Competitiveness of Developing Countries: An Example of the Philippines." Asia Pacific Management Review 9 no. 2 (2004): 301-21.

Waterbury, John ve Diğerleri. A Political Economy of the Middle East. Fourth Edition. USA: Westview Press (2015).

World Bank. Doing Business 2010. Washington DC (2009).

World Bank. Doing Business 2012. Washington DC (2012).

World Bank. Doing Business 2014. Washington DC (2013).

World Bank. Doing Business 2015. Washington DC (2014).

World Bank. Privatization Database (1990-2008), 22.07.2017. http://data. worldbank.org/dat acatalog/privatization-database.

World Bank. World Development Report 1997: The State in a Changing World. Washington D.C. (1997).

World Bank. World Governance Indicators 1996-2015. 22.07.2017. http:// info.worldbank.org/governance/wgi/\#home.

World Economic Forum and European Bank for Reconstruction. The Arab World Competitiveness Report 2013 (2013).

World Economic Forum. The Global Competitiveness Report 2008-2009. ed. Michael E. Porter ve Klaus Schwab (2008).

World Economic Forum. The Global Competitiveness Report 2016-2017. ed. Klaus Schwab (2016). 